\title{
THE SPATIAL AND FUNCTIONAL STRUCTURE OF THE SETTLEMENT FROM THE EARLY IRON AGE IN MILEJOWICE, SITE 19, DISTRICT WROCŁAW, IN THE SOCIAL ASPECT
}

In this paper the authors present the results of spatial analyses performed using GIS tools which were used to recognize the spatial and functional structure of the settlement in Milejowice, site 19, dating back to the Early Iron Age. The aim of the study was to more precisely define the function of the discovered complexes with pole construction buildings arranged around an empty area and to make another attempt at gaining insight into the structure of the society that lived in the settlement. The acquired results allowed a discussion on the earlier interpretations of the settlement in Milejowice, according to which a part of the site functioned as a seat of the elite who distinguished their place of residence with circular fences. The results of GIS analyses did not make it possible to precisely determine the character of the society that inhabited the site. However, in the opinion of the authors, the specific organization of spatial development in Milejowice, taking into account the distribution of different kinds of artifacts within its area, may indicate social stratification among the inhabitants. The basis of the stratification was, above all, access to prestige goods and the division of social roles connected with particular economic or professional activity.

KEY WORDS: spatial analysis, GIS, Thiessen Polygon Method, settlement pattern, Early Iron Age, Hallstatt C, Milejowice site 19

\section{INTRODUCTION ${ }^{1}$}

Archaeologists focus basically on the activities of people in the past, reconstructed on the basis of diverse sources, mainly material ones, whose differentiated character is a significant research prob-

1 The article was prepared as part of grant no. 2015/17/B/HS3/01314 (Opus 9) of the National Science Centre, realized in the Institute of Archaeology and Ethnology of the Polish Academy of Sciences in Warsaw, titled Spatial and functional structures of settlements in the Early Iron Age in Silesia in a social aspect, under the supervision of prof. dr hab. Bogusław Gediga. lem that is often discussed in the source literature (Maetzke 1986; Tabaczyński, Zalewska 2012). In the context of these interests, forming and experiencing landscapes has recently become a significant research area in archaeology concerning the activities of past populations. Space is a dimension in which one tries to achieve goals that are important from the perspective of their existence: utilitarian, functional, social, economic. However, research approaches represented within landscape archaeology often draw upon to differing paradigms, and are also connected in differing degrees with settlement studies, more established and traditional in archaeology. The situation is similar with the range of 


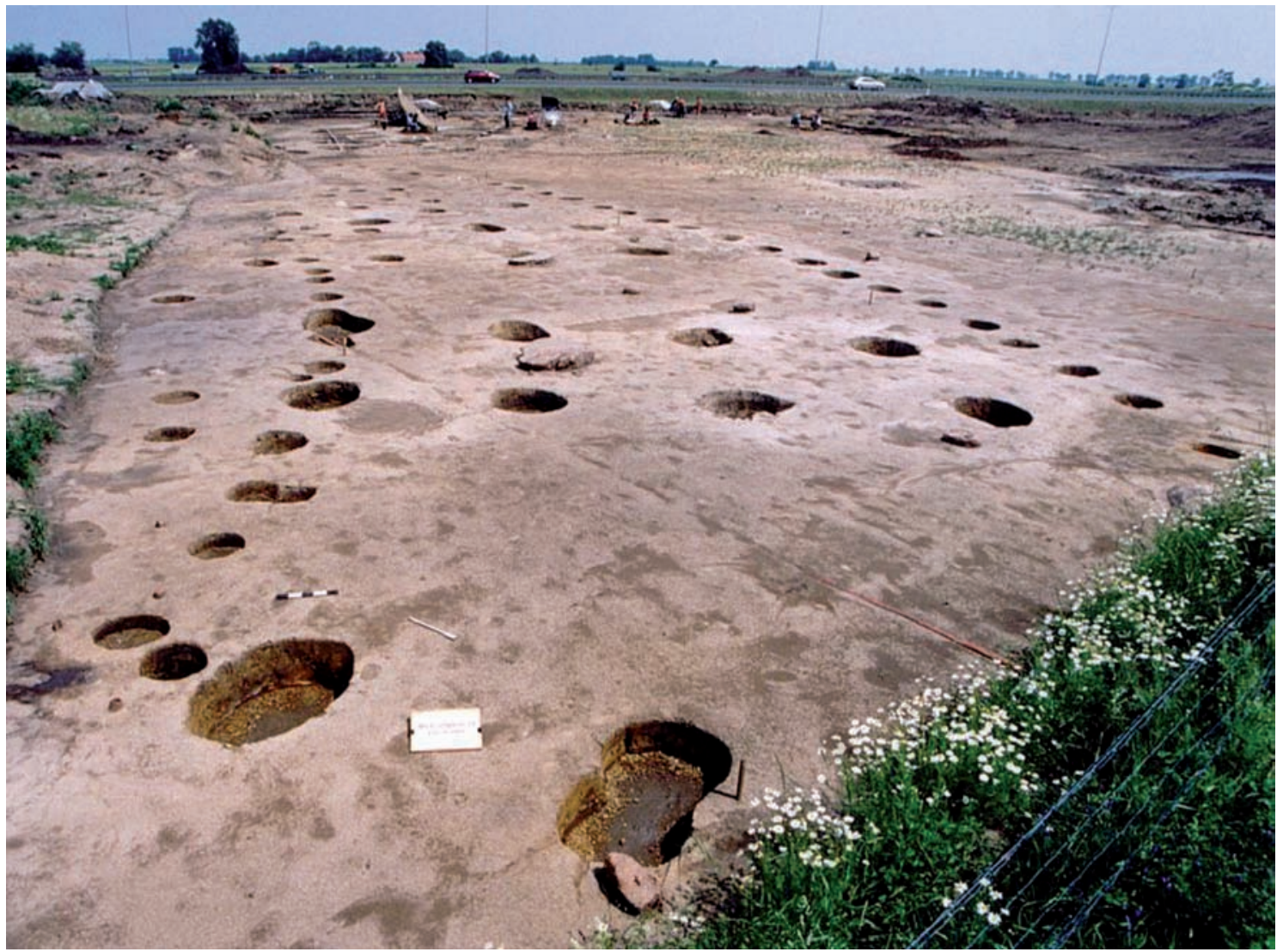

Fig. 1. The elements of fencing and pole construction buildings at the site of Milejowice 19. View from the south (by M. Grześkowiak - Archive of the Rescue Excavations Unit of the Institute of Archaeology and Ethnology of the Polish Academy of Sciences in Wrocław)

methods adopted from the nature sciences, more or less extensively implemented in the studies on past landscapes or settlement processes, and therefore involves them having been adjusted to the physical or humanistic perspective (David, Thomas 2008 - with further literature).

The Geographical Information System (GIS) is a useful tool, widely used in archaeology nowadays to formalize and objectify spatial analyses at different scales. However, the implementation of GIS tools in archaeology faces numerous problems (Raczkowski 2012, 395-397) that we will try to limit in this study, aimed as it is at interpreting the spatial and functional structure of the settlement from the Early Iron Age in Milejowice, site 19 (Fig. 1). What matters most is to avoid perceiving the relationship between humans in the past and the natural environment in Milejowice in a static and deterministic way, and also not to reduce human activity, whose traces are represented by the available sources, only to the economic sphere, even though it shall be the main focus of the paper. In other words, it is im- portant to see other elements of human activity at the settlement of Milejowice 19, the aim of which was to give meaning to the surrounding reality and create a place of certain social identity (Lock 2001, 156), and also to make an attempt at describing the social differentiation of the community.

The earlier analyses and interpretations of the settlement in Milejowice that can be found in source literature, often focused on the character and social differentiation of its population. The studies were concentrated mostly on the outstanding spatial organization structure of the settlement with clearly distinguished building complexes (a detailed analysis will be provided later), ones unique in comparison with the earlier known ones. This was usually considered a reflection of changes in the sphere of social relations that occurred in the Early Iron Age throughout the vast areas of western, southern and partly central Europe. The aforementioned changes, mainly as a result of the influences that flowed directly from the Hallstatt zone, brought about the formation of a leading social layer that reached for 
the patterns used by the "aristocracy" in the Hallstatt cultural zone and separated their impressive dwellings also in other areas of Europe. Researchers have tabled a hypothesis that the distinguishing social group inhabiting the settlement in Milejowice did this as well, which is confirmed by the existence of separated complexes, especially the one surrounded by a kind of a palisade (Bugaj, Gediga 2004; Gediga 2004; Bugaj, Kopiasz 2006; Bugaj, Kopiasz 2008; Kopiasz 2008).

The ongoing archaeological research that resulted in the discoveries of settlements with visibly distinguished complexes of buildings in the area of Poland and neighboring lands further contributed to proposing new interpretations, ones more focused on their practical and economic aspects, as well as to a critical view of the aforementioned interpretation of building development in Milejowice in the social aspect (Baron et al. 2011). The example of the spatial arrangement of the settlement of Milejowice was also confronted with the building layout of Biskupin and became a basis for the studies on the possible models of societies that lived in both places. This approach found inspiration from the discussion on the "sociology of architecture" which, to put it briefly, perceives a particular type of architecture as a materialized social phenomenon (Trebsche 2010, with further literature).

In the summary of this paper all these approaches will be discussed again and verified. The conclusions drawn from the analysis of spatial organization of buildings within the settlement and distribution of certain categories of artifacts in its area have key importance for the discussion. On the one hand, they are supposed to give an answer to the questions regarding past settlement processes and their conditions, and on the other hand, they should help to evaluate the earlier findings based often on an intuitive overview of the distribution of artifacts at the site of Milejowice 19.

\section{THE NATURAL CONDITIONS SURROUNDING THE SITE IN MILEJOWICE}

When it comes to the physiographical aspect, the site in Milejowice is situated in the area of the Wrocław Plain, which is a part of the physical-geo- graphic mesoregion of the Silesian Lowlands. The mesoregion is characterized by a relatively flat or slightly corrugated surface, with no significant altitude differentiation (Sadowski, Włodarski 2004, 3). Within the area covered by the archaeological research very little diversity of terrain relief was observed. The average altitude in the region varies only from 130 to $140 \mathrm{~m}$ above sea level (Fig. 2).

The analyzed site is located in the area of a slightly sloping morphological edge, which from the south-west side comprises a border of a quite broad denudation basin, presently hosting two streams - the Żalina and Żurawka, both being rightbank tributaries of the Ślęza. From the south-west side the morphological edge gently turns into a moraine upland with a slightly corrugated surface, while from the north-east side it forms a vast denudation basin, ca. $6 \mathrm{~km}$ long (Fig. 2-3).

The terrain relief of the site's surroundings is the result of various geological processes that had taken place in the Quaternary Period. This primarily includes denudation, erosion, and glacial and fluvial accumulation (Sadowski, Włodarski 2004, 4). The processes occurred in a wide mesoscale range in the area of the Wrocław Plain already from ca. 240,000 to 220,000 years ago, during the period of deglaciation of the Odra land glacier, which did not cause considerable denivelation changes in this region (Chmal, Traczyk 2001, 11).

The geological structure of the surroundings of the site in Milejowice is illustrated by three lithological cross-sections done with hand probing augers, reaching a depth of $3 \mathrm{~m}$ below the ground level (Fig. 2, 4). The mottled clays deposited in the lowest layers are the oldest formations, and are dated to the tertiary Miocene/Pliocene. They were observed in hole no. 2 at a depth of $0.9 \mathrm{~m}$, directly under the soil layer. Clays were probably also present under a layer of quartz and silt sands in holes no. 1 and 3, at a depth of at least $1.7 \mathrm{~m}$ (Fig. 4).

Directly on tertiary mottled clays, which belong to the clays of the Poznań series, usually glacial sediments of the Riss Glaciation are deposited (Sadowski, Włodarski 2004, 6). The sequence of the geological formations in the surroundings of the site in Milejowice begins with fluvioglacial sands, gravels, and silts deposited during the anaglacial phase of the Riss Glaciation, i.e., in front of the sliding glacier. They are visible in the form of silty-clay sands mixed with gritty diamicton at a depth of 1.4-1.2 $\mathrm{m}$ in hole no. 1 (Fig. 4). Further 


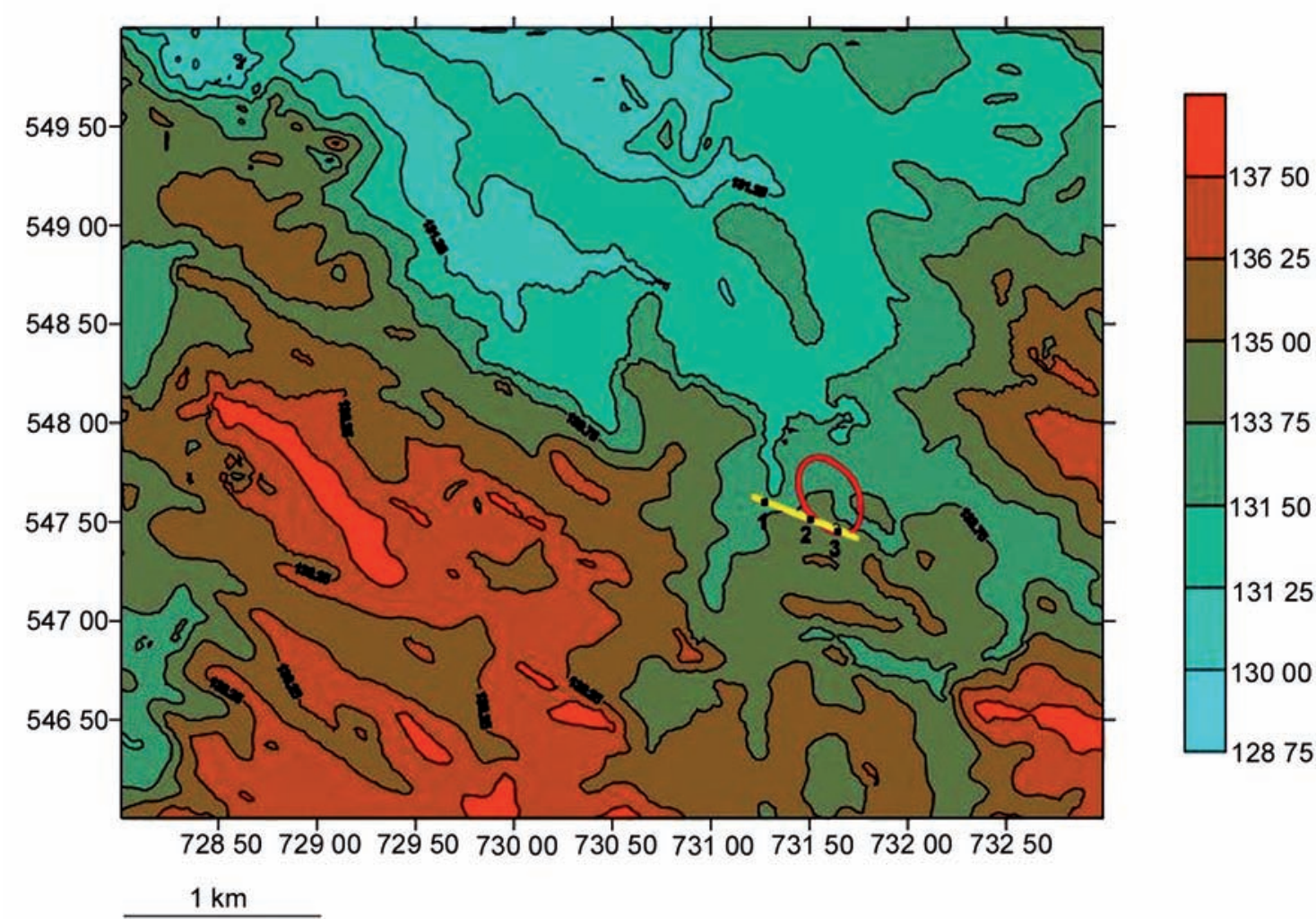

Fig. 2. The location of the site of Milejowice 19 (marked with an ellipse), geological cross-section (yellow line) and profiles done with the use of a probing auger shown against the topographic contour map of the site's area (by K. Sadowski - Archive of the Rescue Excavations Unit of the Institute of Archaeology and Ethnology of the Polish Academy of Sciences in Wrocław)

phases of geological processes connected with the glacier's impact on the area surrounding the site in Milejowice can be associated with the late phase of sedimentation processes that took place in front of the retreating land glacier of the Riss Glaciation. The phase is represented in the lithological profiles of the analyzed area by silty sands and sandyclay silts that formed most probably as a result of the sedimentation of marginal deposits, observed at a depth of $0.75-0.85 \mathrm{~m}$ in holes no. 1 and no. 3 (Fig. 4).

Younger quaternary formations are represented in the analyzed area by various kinds of fluvial facies. Fluvioglacial silts and sands of the Warta Glaciation, forming a long lobe stretching along the axis of a linear denudation basin, used now by the riverbed of the Żalina. Fluvial sediments of the Holocene are represented by silts, gravels, and sands. In the area of the denudation basin, they cover the bottoms of linear lowerings that presently serve as stream beds of the Żalina and Żurawka (Fig. 2-3). In the geological profile of the site's sur- roundings the layers are represented by sand and silt formations deposited at a depth of 0.5-0.6 $\mathrm{m}$ in hole no. 1 (Fig. 4).

It is worth emphasizing that all glacial formations and deposits, commonly found in the vicinity of the site of Milejowice 19 and other areas of the whole Wrocław Plain, can be an important source of information in the settlement studies. As geomorphological-geological studies conducted by H. Chmal and A. Traczyk in the area of the Wrockaw Plain indicate, on the sites threatened by the construction of the A4 highway most boulders and erratic boulders that come from the glacial deposits had an intentional position within the sedimentary area. This can be noticed when it comes to both granulometric and petrographic selection of the material, which results, as the researchers noticed, not only from the shallow deposition of the formations at a depth of $0.5 \mathrm{~m}$, but also from the conscious use of them for economic purposes, as various kinds of tool construction elements (Chmal, Traczyk 2001, 11-12). An interesting example of intentional use 

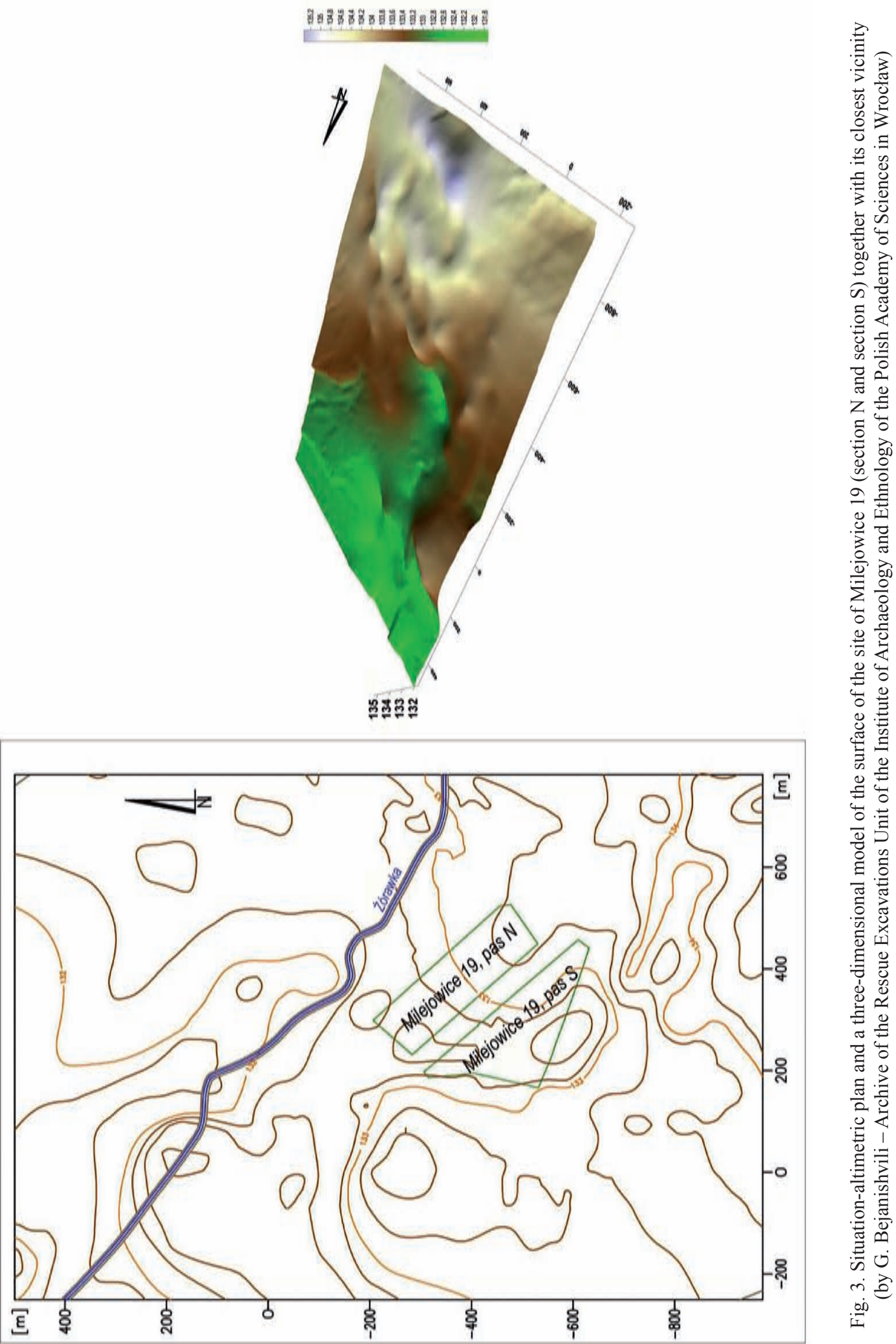

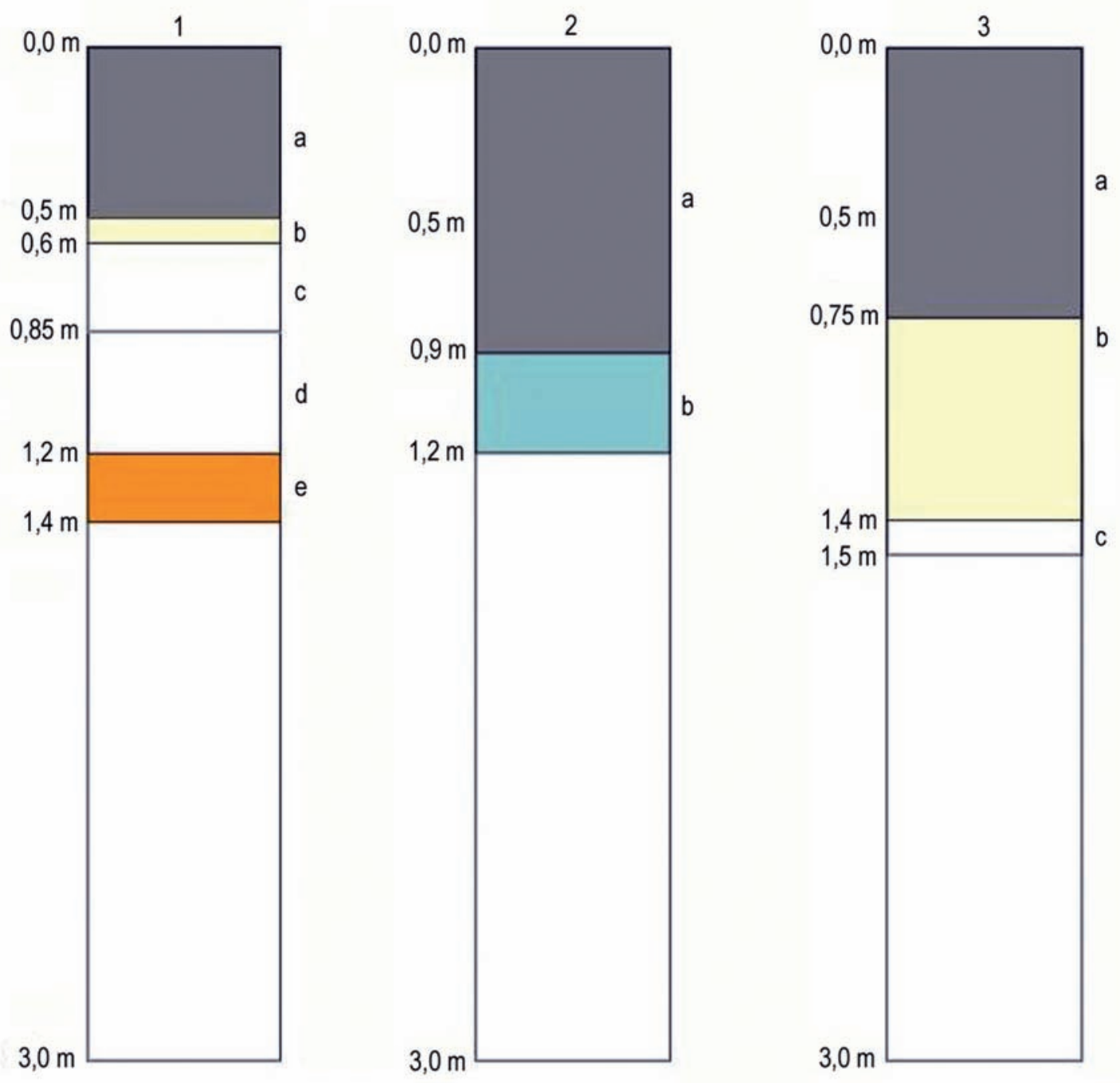

Fig. 4. Presentation of lithological profiles done with probing augers inserted down to a depth of $3 \mathrm{~m}$ below the ground level at the site of Milejowice 19: borehole $1-\mathbf{a}$. black earth soil, b. light grey-yellow sandy silt, c. grey-yellow sand mixed with fine-grained grit, d. grey-yellow gravelly sand, e. light grey-yellow silty-illitic sand; borehole 2 - a. black earth soil, b. grey-yellow Poznań clays; borehole 3 - a. black earth soil, b. grey-yellow silty sand, c. grey-yellow sand mixed with fine-grained grit (by K. Sadowski - Archive of the Rescue Excavations Unit of the Institute of Archaeology and Ethnology of the Polish Academy of Sciences in Wrocław)

of a stone whose shape, size, and weight definitely prevented it from being moved, is a flat boulder - an erratic block of a large size, $1 \mathrm{~m}$ wide and $1.8 \mathrm{~m}$ long, located "in situ" at the settlement of Milejowice 19 ( $\mathrm{N}$ belt), close to utility features. In this context it could have functioned as a table or a platform used for practical or ceremonial purposes (Bugaj, Gediga 2004, 224 and fig. 11).

In the whole area of the site in Milejowice, in its surroundings and also in a wider territorial context - including the uplands of the Wrocław Plain a black earth type of soils developed. In the lithological profiles from boreholes no. 1 and no. 3 , done in the close surroundings of the site in Milejowice, it was observed that the soil horizons reached a depth of 0.5-0.7 m. Directly under the humus layer there was parent material, i.e., silty sands belonging to the complex of loessal silts and their deluvials (Sadowski, Włodarski 2004, 8; Fig. 4). Similar conclusions regarding the origin of black earths in the area of the Wrocław Plain were presented by H. Chmal and A. Traczyk in their work. According to these researchers, black earths formed on the loess-like formations, being geologically mainly dusty-clay sands, dusty clays, and clay-sandy silts, which lets us classify them as medium and heavy loams and clay dusts. It should be added that the soils formed while being impacted by grasses or grasses with 
herbaceous plants, under conditions of high ground humidity, which results from the shallow ground water placement. In the turf-forming process large amounts of substances that underwent humification were produced. When it comes to botanization, the black earths of the Wrocław Plain belong to the best ones in Poland. Such a state regarding soils, lasting since the prehistoric period, results from the relatively flat landscape with no erosion and non-destructive agriculture (Chmal, Traczyk 2001, $28,30)$.

The potential natural vegetation of the uplands of the Wrocław Plain was represented in prehistory by the Central-European broadleaved forest. The bottoms of the valleys of the rivers Ślęza and Oława are believed to have been occupied by ashelm riparian forests, while the bottoms of secondary stream valleys, like the Żurawka, were covered by elm riparian forests (Chmal, Traczyk 2001,31 - with further literature). During archaeological rescue excavations in the area of the A4 highway analyses were carried out of palynological sediments from the bottoms of wells discovered on several sites in the vicinity of Milejowice. In the pollen spectra from the well fills, pine (and to a lesser extent also fir and spruce) predominated. The trees were typical of habitats of low fertility, sand, or sand-gravel soils. They do not naturally occur in the areas where black earths dominate. The discrepancy between the findings of palynologists and geologists can be explained by the wide dendrochronology determined for the wooden boards from the aforementioned wells (Hallstatt Period - Middle Ages), however, most wells should be associated with the Roman Period, i.e., the time when the studied area was already almost entirely deforested. Only clumps of coniferous trees were present on local hills that were not occupied by agriculture due to the poor fertility of the soil which formed on sands and gravels without the cover of loess-like formations. Further palynological and radiocarbon analyses carried out during the excavations on Wrocław's fragment of the A4 highway, including those in the surroundings of Milejowice, indicated that riparian forests remained in the river valleys until ca. $650 \mathrm{BC}$, while the time of their most intensive development was around 800 BC (Chmal, Traczyk 2001, 31-32). Riparian forests were a perfect source of construction wood and firewood in prehistory. In the case of the settlement in Milejowice, where numerous traces of wooden pole constructions were recorded, the wide availability of construction material was of key significance for its development.

\section{THE STAGES OF SETTLING THE SITE}

In the excavated area of site no. 19 in Milejowice relics of a settlement from the Early Bronze Age and the remains of a settlement from the Late Bronze Age and the Hallstatt Period were discovered (Bugaj, Gediga 2004, 217; Kopiasz 2004, 31, 57). Undoubtedly, the oldest prehistoric traces of human presence in the area of the site of Milejowice 19 are connected with the population of the Unětice culture, whose inhumation cemetery is located there. A total of nine graves were preserved, including a multi-person one. In terms of chronology, all graves were connected with phase I and phase II of the Únětice culture, which is indicated by artifacts typical of this period, mostly ceramic ones (Kopiasz 2004, 34-45, 48-51). The graves were scattered throughout the area of the site. The burials were mostly single ones or in pairs and in one case there was a group of three burials close to each other. They were quite distant from one another, from a few up to over ten meters apart. All features of the Únětice culture were recorded in the west part of the site. When it comes to the stratigraphic position, no relations between the Early Bronze Age graves and the Hallstatt features were observed, even though they were located in direct proximity (Fig. 5).

During a preliminary analysis of sources, grave no. 969 , located in the north part of the site, was not classified in a group of finds related to the Early Bronze Age. The reason was probably its different and atypical form, compared to other burials from the Early Bronze Age. The grave's distinctive feature was the complete lack of grave goods, which made it impossible to precisely define its chronological position. The body was placed in the burial pit straight on its back, with arms bent at the elbows and the head slightly tilted eastwards. Such a position of the body in a burial pit is rare among the finds of the Únětice culture, unlike the typical fetal position on the side (Butent-Stefaniak 1997, 194, plate $34: 1 b$ ). In order to determine the chronology of this grave a bone sample for radiocarbon dating was taken. The acquired calibrated date strongly 
indicates ( $83.5 \%$ probability) that the grave was founded in the Early Bronze Age and presumably belonged to the Únětice culture cemetery recorded at the site (Fig. 5, Table 1).

The next stage of settling the site in Milejowice embraces the very end of the Bronze Age and the Hallstatt Period. This is connected with the longterm and probably uninterrupted use of the vast settlement whose preserved relics originally formed complexes of aboveground buildings erected in pole construction and in-ground features of a different functional character (Fig. 5-6). Just as in the case of sources from the Early Bronze Age, also in this case the chronology was defined on the basis of the analysis of artifacts as well as the absolute chronology provided by radiocarbon dating and tree-ring dating (Goslar 2004; 2006; 2019; Krąpiec 2001a; 2001b; Fig. 5, Table 1).

The largest group of finds discovered during the excavations of the settlements in Milejowice are fragments of ceramic vessels. During several seasons of excavations (1999-2002) 53,364 fragments of various kinds of ceramic vessels were found. Already during the preliminary exploration of features and the cultural layer it was possible to identify the cultural and chronological relation of the finds and match them with the late phases of the Bronze Age and, first of all, Hallstatt C. Further excavations conducted in 2001-2002, providing the great abundance of source material, confirmed the chronological attribution of the settlement (Bugaj, Gediga 2004, 217-218).

During the excavations, preliminary verification of relative chronology was also performed using radiocarbon and tree-ring dating methods. Samples of animal bones from features that contained pottery characteristic of the Hallstatt $\mathrm{C}$ period were chosen for analysis. Radiocarbon dates obtained in the laboratory in Gliwice indicated the time span of $2750 \pm 110$ BP (Pazdur 2001). Further radiocarbon analyses, performed in the Poznan Radiocarbon Laboratory, which has the equipment that uses the more precise AMS method of dating, indicated the late phase of the Hallstatt Period: $2380 \pm 35$ BP (Goslar 2004). A sample for analysis was taken from the feature located in the south part of the settlement, where fragments of Hallstatt painted pottery were found in the fill (Bugaj, Kopiasz 2006, 178, 198). Both absolute chronology indications clearly show that the settlement had been used very long, which is also confirmed by the traces of repairs and alterations of pole buildings and also dugouts that were found in the places where aboveground buildings had functioned (Fig. 6).

Indications of absolute chronology for these settlement were also obtained using dendrochronology in the laboratory of the AGH University of Science and Technology in Cracow. These analyses were performed by M. Krapiec on the basis of his own local and regional chronological systems for Lower Silesia and southern parts of Poland (Krąpiec 2001a; 2001b; 2003). The samples for the analysis were taken from wooden boards that were used for lining wells no. 53, no. 280 , no. 965 and no. 914 , which were recorded within the distinguished settlement complexes in both excavated strips of land (Fig. 5-6). The dates acquired using this method suggest that all analyzed wells could have functioned in the first half of the seventh century BC (Table 1, Fig. 5). However, we need to bear in mind that this is the time when the tree had been cut down and the possibility of using wood as a construction material appeared, not the moment of building or using the well.

Taking into account the vast area occupied by the settlement from the Late Bronze Age and Hallstatt Period, the over a hundred years of its existence (which has already been indicated by the presented radiocarbon dates), as well as the observed traces of construction interference in its spatial structure, several samples of animal bones were selected for further radiocarbon analyses. The main goal of the chronological analysis was to look for an answer to the following questions: how the spatial development of the settlement proceeded from the Late Bronze Age to the late phases of the Hallstatt Period and whether the dugouts, made in the place of earlier aboveground buildings, were the next phase of development, clearly marked in time. Moreover, it was also important to define the chronological position of all discovered wells, based on the acquired radiocarbon dates $\mathrm{C} 14$ (Table 1).

After the excavations at the site of Milejowice, it was assumed that the settlement appeared at the end of the Bronze Age or at the beginning of the Early Iron Age (Bugaj, Gediga 2004; Bugaj, Kopiasz 2006; Kopiasz 2008). In absolute chronology it could have been the second half of the eighth century BC or the turn of the seventh century BC. Most artifacts from that phase were recorded in the north section of the settlement in Milejowice (Fig. 5-6). Also from the north part of the settlement 
THE SPATIAL AND FUNCTIONAL STRUCTURE OF THE SETTLEMENT IN MILEJOWICE, SITE 19, DISTRICT WROCŁAW

Table 1. Absolute chronology of selected features at the settlement in Milejowice

\begin{tabular}{|c|c|c|c|c|}
\hline $\begin{array}{l}\text { Sample } \\
\text { reference } \\
\text { number } \\
\text { on fig. } 4\end{array}$ & Sample name & $\begin{array}{l}\text { Functional } \\
\text { classification } \\
\text { of the feature }\end{array}$ & $\begin{array}{l}\text { Radiocarbon dating } 14 \mathrm{C} \\
\text { according to T. Goslar }\end{array}$ & $\begin{array}{l}\text { Dendrochronology } \\
\text { according to M. Krąpiec }\end{array}$ \\
\hline 1 & Mil 19/N/969 & Skeletal grave & $\begin{array}{c}95.4 \% \text { probability } \\
\text { 2050BC }(82.7 \%) 1880 \mathrm{BC} \\
\text { 2140BC }(12.7 \%) 2080 \mathrm{BC}\end{array}$ & \\
\hline 2 & Mil 19/S/751 & $\begin{array}{l}\text { In-ground } \\
\text { construction }\end{array}$ & $\begin{array}{c}\text { 95.4\% probability } \\
760 \mathrm{BC}(9.3 \%) 700 \mathrm{BC} \\
540 \mathrm{BC}(86.1 \%) 390 \mathrm{BC}\end{array}$ & \\
\hline 3 & $\begin{array}{c}\text { Mil 19 } \\
\text { 19_331_1501S }\end{array}$ & $\begin{array}{l}\text { In-ground } \\
\text { construction }\end{array}$ & $\begin{array}{c}\text { 95.4\% probability } \\
\text { 781BC }(95.4 \%) 511 \mathrm{BC}\end{array}$ & \\
\hline 4 & $\begin{array}{c}\text { Mil } 19 \\
\text { 334_01_1502S }\end{array}$ & $\begin{array}{l}\text { In-ground } \\
\text { construction }\end{array}$ & $\begin{array}{c}\text { 95.4\% probability } \\
749 \mathrm{BC}(17.6 \%) 684 \mathrm{BC} \\
667 \mathrm{BC}(5.5 \%) 641 \mathrm{BC} \\
588 \mathrm{BC}(0.9 \%) 579 \mathrm{BC} \\
562 \mathrm{BC}(71.4 \%) 403 \mathrm{BC} \\
\end{array}$ & \\
\hline 5 & $\begin{array}{c}\text { Mil } 19 \\
\text { 380_00_749S }\end{array}$ & $\begin{array}{l}\text { In-ground } \\
\text { construction }\end{array}$ & $\begin{array}{c}95.4 \% \text { probability } \\
750 \mathrm{BC}(19.6 \%) 683 \mathrm{BC} \\
668 \mathrm{BC}(6.6 \%) 639 \mathrm{BC} \\
590 \mathrm{BC}(69 \%) 405 \mathrm{BC}\end{array}$ & \\
\hline 6 & $\begin{array}{c}\text { Mil 19 } \\
\text { 19_380_00_61S }\end{array}$ & Undefined pit & $\begin{array}{c}\text { 95.4\% probability } \\
\text { 768BC }(92.4 \%) 476 \mathrm{BC} \\
464 \mathrm{BC}(1.2 \%) 453 \mathrm{BC} \\
445 \mathrm{BC}(1.8 \%) 431 \mathrm{BC}\end{array}$ & \\
\hline 7 & $\begin{array}{c}\text { Mil 19 } \\
\text { 72_00_97N }\end{array}$ & Undefined pit & $\begin{array}{c}\text { 95.4\% probability } \\
\text { 768BC }(92.4 \%) 476 \mathrm{BC} \\
\text { 464BC }(1.2 \%) 453 \mathrm{BC} \\
445 \mathrm{BC}(1.8 \%) 431 \mathrm{BC}\end{array}$ & \\
\hline 8 & $\begin{array}{c}\text { Mil } 19 \\
\text { 285_00_400N }\end{array}$ & $\begin{array}{l}\text { In-ground } \\
\text { construction }\end{array}$ & $\begin{array}{c}\text { 95.4\% probability } \\
751 \mathrm{BC}(23.5 \%) 682 \mathrm{BC} \\
669 \mathrm{BC}(8.9 \%) 636 \mathrm{BC} \\
626 \mathrm{BC}(1.5 \%) 614 \mathrm{BC} \\
592 \mathrm{BC}(61.5 \%) 408 \mathrm{BC}\end{array}$ & \\
\hline 9 & $\begin{array}{c}\text { Mil 19 } \\
\text { 99_00_109N }\end{array}$ & $\begin{array}{l}\text { In-ground } \\
\text { construction }\end{array}$ & $\begin{array}{c}95.4 \% \text { probability } \\
795 \mathrm{BC}(29.3 \%) 728 \mathrm{BC} \\
717 \mathrm{BC}(1.0 \%) 708 \mathrm{BC} \\
694 \mathrm{BC}(65.1 \%) 542 \mathrm{BC}\end{array}$ & \\
\hline 10 & $\begin{array}{c}\text { Mil } 19 \\
\text { 323_01_1493S }\end{array}$ & $\begin{array}{l}\text { In-ground } \\
\text { construction }\end{array}$ & $\begin{array}{c}95.4 \% \text { probability } \\
702 \mathrm{BC}(0.6 \%) 696 \mathrm{BC} \\
541 \mathrm{BC}(94.8 \%) 390 \mathrm{BC}\end{array}$ & \\
\hline 11 & $\begin{array}{c}\text { Mil 19 } \\
\text { 94_00_246S }\end{array}$ & Undefined pit & $\begin{array}{c}\text { 95.4\% probability } \\
776 \mathrm{BC}(95.4 \%) 488 \mathrm{BC}\end{array}$ & \\
\hline 12 & $\begin{array}{c}\text { Mil 19 } \\
\text { 186_01_1201S }\end{array}$ & Undefined pit & $\begin{array}{c}\text { 95.4\% probability } \\
\text { 481BC }(3.2 \%) 440 \mathrm{BC} \\
434 \mathrm{BC}(90.0 \%) 358 \mathrm{BC} \\
276 \mathrm{BC}(2.2 \%) 257 \mathrm{BC}\end{array}$ & \\
\hline 13 & $53 \mathrm{~N}$ & Well & & $630 \mathrm{BC}$ \\
\hline 14 & $280 \mathrm{~N}$ & Well & & $635 \mathrm{BC}$ \\
\hline 15 & $965 \mathrm{~N}$ & Well & & $611 \mathrm{BC}$ \\
\hline 16 & $914 \mathrm{~S}$ & Well & & $613 \mathrm{BC}$ \\
\hline
\end{tabular}


comes the bone sample whose radiocarbon dating confirms such a chronological position (Pazdur 2001). At the same time, apart from older artifacts, in many features numerous typically Hallstatt artifacts were found, such as fragments of vases with a funnel-shaped mouth and a conical neck, or painted pottery (Kopiasz 2008, 221, fig 10). Radiocarbon dates acquired from the samples of animal bones that were found in dugouts and storage pits also confirm the indicated chronological position (Table 1). The sample dated to 592-498 BC is an exception and, in connection with the traces of alterations of the aboveground buildings in complex $1 \mathrm{~N}$ (Fig. 5-6), it can indicate the younger phase of the settlement's existence. Further absolute dates from complexes $2 \mathrm{~N}$ and $3 \mathrm{~N}$ also indicate seventhsixth century BC (Table 1). The objects within the south section should be associated with this chronological phase as well. The acquired radiocarbon dates place the sources from that area in the period between the seventh and sixth century BC and in the younger phase - in the fifth century - which is connected with different kinds of transformations in the south-west part of the site, within the area of complex $3 \mathrm{~S}$ and its close vicinity (Fig. 5-6). In the case of complex $3 \mathrm{~S}$, which was the largest one in terms of the surface, interesting is the chronology of the inner pole fences and ditches that surround the building. Assuming that the oldest element of the complex is the outer circular fence, and well no. 914 discovered there is dated to the first half of the seventh century BC, we can state that the pole fence must have been erected at the same time that the well was built, or a little earlier. Other inner fences marked the next phase of functioning of this part of the settlement, which could have happened in the sixth-fifth century BC (Table 1).

The acquired absolute chronology suggests that the beginnings of the settlement in Milejowice can be associated with the very late phases of the Bronze Age and the beginnings of Hallstatt C, so most probably the eighth century BC. The oldest traces of the settlement are represented by the finds from complexes $1 \mathrm{~N}, 2 \mathrm{~N}$, and $3 \mathrm{~N}$ and very few from the south part. In the seventh century BC, when the wells in all complexes were built, the settlement was in its heyday, regarding the spatial and probably functional aspects, too. In this period the circular 3S complex with an inner fence also functioned. In the younger phases of the settlement's existence many changes related to the development of eco- nomic activity in the west part of the south section took place, which happened in the fifth century BC. The date indicating the period of 434-358 BC is the latest trace of human activity at the settlement in Milejowice, site 19.

\section{METHODS OF RESEARCH}

For the analysis of the spatial and functional organization of the settlement in Milejowice 19, sources were acquired during rescue excavations carried out in 1999-2002 (Bugaj et al. 2002; Bugaj, Gediga 2004). All of them were precisely documented and preliminarily analyzed with a focus on defining the site's chronology, stages of settling the area in the prehistoric period, and cultural classification (Kopiasz 2004; Bugaj, Kopiasz 2006). During the realization of the scientific goal of this study information contained in the feature charters, prepared during the excavations and directly after they had been finished. This information includes the location of the object, its size, the character of the fill, stratigraphic relations, type and number of artifacts found, as well as function and chronology. A rich data set was also acquired from the artifact inventories, from both the features and cultural layer present in some parts of the site. In the analysis of the function of the settlement features the following characteristics of the artifacts were taken into account: number, the material which the item was made of, utilitarian function, cultural and chronological classification. The functional and chronological identification was supported by references to analogous finds from the sites of similar chronology known from the literature. The basic and the most important source of information in the research on the spatial and functional structure of the settlement in Milejowice 19 was the graphic plan of the whole site, which was prepared using CAD right after the documentation works had been finished. The plan contained information regarding the scope of the excavations, localization of the features, and their mutual relations in the horizontal stratigraphy. During the long-term studies on the sources from the site of Milejowice, the plan was complemented with new data, among others: a functional interpretation of the objects, chronological identification, and spatial distribution of se- 
lected categories of sources (Bugaj, Kopiasz 2006; Kopiasz 2008; Bugaj, Kopiasz 2008).

For the needs of research, the above mentioned set of sources was used for building an attribute database - a geodatabase using GIS application (ArcGIS). The database is a vast source of information concerning the spatial distribution of all features recorded on the site and their characteristics. The resources of the geodatabase are available as both vector graphics (lines, polygons, points) and descriptions that consist of text and numeric data. The basis for creating the base, as mentioned earlier, was a vector plan of the site, prepared using CAD software. After implementing it to ArcGIS, a topology for all features was carried out and the information was systematized considering the planned analyses. Further, datasets of the following data were defined in the geodatabase: "archaeological features", "cultural layer", "chronology" and "trench". In the dataset "archaeological features" classes, distinguished basing on their function determined earlier in a feature charter, were created. The following classes were distinguished: "post holes", "buildings", "dugouts", "fencing elements", "wells", "bronze-working workshop", "storage pits", "resource pits", and "offering pits". The dataset "cultural layer" contained information regarding the numbering of particular ares where the artifacts were discovered and the information on cultural content, including the number of artifacts, material, function, chronology. Those are the attributes that characterize each fragment of the cultural layer, separately described in the geodatabase and referring to a separate fragment of the excavated site area. In the same way the data regarding the attributes for the aforementioned classes was entered in the dataset "archaeological features". The third dataset in the geodatabase referred to the chronology. Information on the relative and absolute chronology was included in it. The last dataset consisted of the information on the spatial scope of each season of archaeological research. Based on this, a layer presenting the overall excavated area was created. The areas between the trenches which were not available for archaeological excavations were also included. From the perspective of spatial analyses, the exclusion of those areas from the research is not well justified. In this work they are treated as areas that belong to the site but do not contain any archaeological material.
The next stage of the research focused on the recognition of the spatial and functional organization of the settlement in Milejowice, site 19, was that of spatial analysis using the Thiessen Polygon method. The aim of the analysis was to illustrate the distribution of the class "buildings" within the area of the settlement and the attempt to define the models of their spatial arrangement in reference to one another and other features. It should be emphasized that in this paper an assumption was made that the class "buildings" has the same functional status in the whole organizational structure of the settlement, related to residential function or combining residential and economic activity.

Thiessen polygon analyses were already applied in archaeological settlement studies numerous times, both on a regional scale and concerning single sites, where they proved very useful in the complex research process (Kobyliński 1988, 78; Kadrow 1991, 74, 81; Skowron 2007, 23; Przybyła, Blajer 2008, 38; Buchner 2013, 791; Buchner 2018, 368-369).

Thiessen polygons are polygons characterized by the fact that any given point or place inside the polygon is always located closer to a point inside it than to another control point (Urbański 1997, 73; Ciesielska 2001, 7). In this work "buildings" were selected as control points. The choice of the class of "buildings" for analysis was dictated by two aspects. Firstly, the aboveground buildings had a pivotal impact on the shape of other structures within the settlement area. They created a kind of landscape, to which other elements were adjusted, such as in-ground constructions or fencing and fortification elements. The other important factor that determined the choice of this category of finds were purely economic reasons, such as increased expenditures, workload, and time-consumption necessary for erecting a pole construction building. The importance of buildings in reference to the whole architecture of the settlement in Milejowice is also confirmed by numerous traces of alterations, repairs, and relocations, which was not observed in the case of other objects, such as dugouts, which were most probably abandoned after they had been fully exploited. In order to carry out an analysis of Thiessen polygons, aboveground constructions, defined in the geodatabase as "buildings", were transformed into a layer of points and later polygons (whose borders were included in the layer's "site area") and were drawn on the basis of their 
location. Further, classification of polygons using quantile estimation method, which presents the distribution of one numeric value of the studied phenomenon or analyzed feature within a given class of objects, was carried out (Medyńska-Gulij 2011, $115)$. In this case the classification was based on the surface area of the polygons, given in meters. There were six classes distinguished altogether. On the prepared map, the areas marked with the highest saturation of color present the smallest surface of polygons, indicating at the same time the highest density of "buildings" compared to the neighboring areas, and also the smallest area that they had an impact on. In the case of the areas marked with the least intense color the situation is the reverse. Each of the quantile classes refers to the intensity of the analyzed phenomenon (Fig. 7).

The next stage of the analysis based on Thiessen polygons included imposition of the outlines of "buildings" over the polygons map and further observations of possible relations between their orientation and the shape of the polygons. Later added were also other features that received the following functional definitions: dugouts, wells, storage pits, offering pits, resource pits, ditches etc. The prepared map was used to study functional aspects of the settlement in Milejowice (Fig. 8).

In the next stage the analyses of distribution of particular groups of artifacts found in the features and cultural layer were carried out. The created maps contained information on the location of pottery, which is the most numerous and most common archaeological source on each settlement site, and also maps of distribution of bones, burnt clay as well as metal, stone and clay objects, in the form of both loose mass material and functionally defined tools. All graphic presentations of the distribution of artifacts within the area of the settlement have become a basis for further studies in the next stage of the research process and for the conclusions regarding the function of the features and distinguished complexes of buildings (Fig. 8, 10, 12).

During the preparation of the maps of distribution of particular characteristics of features, such as function, location of each kind of artifacts, the area covered by the cultural layer or presentations of selected categories of sources by numbers, the methods of symbolization and visualization using one or several attributes for the qualitative data and classification in the case of figures were used (Urbański 2008, 87-91). An example of classification per- formed using the quantile estimation method is the map of Thiessen polygons (Fig. 7). All maps presenting the data as figures are choropleth maps, i.e., statistical maps which show the average intensity of a phenomenon within reference fields into which the analyzed area was divided. The figures in those maps are ordered in the form of intervals in the determined class ranges (Medyńska-Gulij 2011, 115).

\section{THE SPATIAL AND FUNCTIONAL STRUCTURE OF THE SETTLEMENT IN MILEJOWICE}

A very large area of the settlement in Milejowice (737.5 ares) was excavated. Due to the high levels of groundwater in the south-west part of the site, some features were unavailable for exploration or had been completely destroyed. Also a small part between the north section and the south section was inaccessible. Despite the inconveniences we managed to record most of the settlement remains; however, it probably was not a complete image of its spatial extent (Fig. 6).

Thanks to these excavations, which were carried out in Milejowice on a very large scale, it was possible to undertake research focused on the analysis and interpretation of the functional structure of the settlement, which was characterized by a remarkably clear and regular distribution of features (Fig. 1, 6). Because of the huge scale of sources represented by the material from Milejowice, unprecedented in Silesia, numerous attempts were made in the literature at defining the functional and spatial organization of development within the area of the discussed site (Bugaj, Gediga 2004; Gediga 2004; Bugaj, Kopiasz 2006; Kopiasz 2007; Kopiasz 2008; Bugaj, Kopiasz 2008; Markiewicz 2019). The first findings regarding the overall picture of the settlement in Milejowice and its cultural and chronological identification were made right after the excavations had been finished. Further works concerning the sources from the discussed site were focused on two underlying aspects: the functional interpretation of particular elements of the settlement's structure and identification of the model according to which the settlement's space was organized (Bugaj, Kopiasz 2006). Studies on the connections of the settlement model recorded in Milejowice with 
the social changes that were in progress in the beginning of the Hallstatt period, as determined by contacts with the East- and West-Hallstatt cultural zone, were also of importance (Gediga 2004; Kopiasz 2007; Kopiasz 2008; Bugaj, Kopiasz 2008).

The functional classification of the sources presented in earlier works includes the following categories of objects: aboveground buildings constructed with 6-8 poles and two buildings with more poles (Fig. 6 - in complexes $1 \mathrm{~N}$ and $3 \mathrm{~S}$ ), used for residential and economic purposes, in-ground constructions for residential and economic purposes (dugouts), wells, storage pits, metallurgy workshop, resource pits, votive pits, fencing ditches, pole fencing elements, and pits of undefined character, probably used for utilitarian purposes (Fig. 6). The classification presented by E. Bugaj and J. Kopiasz in one of the publications was adopted in this paper as a basis for the analyses and studies defined for the research goals (Bugaj, Kopiasz 2006; Kopiasz 2008). Graphic models of outlines of particular residential-economic complexes, defined by J. Kopiasz, were also taken into consideration. The complexes $1 \mathrm{~N}, 2 \mathrm{~N}, 3 \mathrm{~N}, 1 \mathrm{~S}, 2 \mathrm{~S}$, and $3 \mathrm{~S}$ were distinguished by the scholar on the basis of the areas of the largest concentration of ceramic finds discovered in the features and cultural layer (Kopiasz 2008, 214, fig. 3; Fig. 6).

The earlier research on the spatial and functional organization of the settlement in Milejowice revealed that the distribution of particular features was carefully planned, repetitive, and in line with the construction rule recognized by T. Gralak for the Hallstatt Period, connected with using a certain size standard for pole construction row buildings (Gralak 2013, 339). Apart from Milejowice, this construction rule was observed also in several settlements from the Hallstatt Period. Here are some examples of sites from Lower Silesia: the settlement in Stary Śleszów (Kopiasz 2003), Zabrodzie (Baron et al. 2011), and the Czech Republic: Podoři (Tajer 2016) and Opatovice nad Labem (Vokolek, Sedláček 2010). Based on Lower Silesian examples, it can be concluded that in the Hallstatt Period in that area a repetitive model of spatial organization of settlements functioned. The concept was based on locating building and adjusting constructions as complexes that form a circle or a square with rounded corners around an empty yard. The whole was surrounded with fences or ditches whose shape was also circular or square with rounded cor- ners. Such an ideal plan can be observed in Stary Śleszów and Milejowice, and to some extent it was represented in Zabrodzie (Kopiasz 2003; Bugaj, Kopiasz 2006 and 2008; Baron et al. 2011). In the case of other areas remaining under the influence of the Hallstatt culture the form of the model was different, basing mostly on square plan. Similar structures, known from Bavaria, are referred to as in the literature as "Herrenhof" or "Herrensitz", which can be translated as "manor" (Polish pański dwór) pańska siedziba) (Gralak 2013, 339, with further literature.). A similar form of spatial organization was represented by the settlement in Opatovice nad Labem (Vokolek, Sedláček 2010).

The main goal of this work is the attempt at answering the question: what functional role could particular structural elements of the settlement (building complexes and economic zones) in Milejowice have served? It is also important to outline a hypothetical picture of the society that inhabited the settlement, assuming that any spatial form created as a result of human activity reflects to some extent the norms prevailing in this society (Buchner 2018,365 , with further literature).

The most important structural element in the organization of the development of the settlement in Milejowice, as mentioned earlier, was that of the aboveground buildings supported by $6-8$ poles, or bigger ones, constructed using over ten poles. Numerous traces of repairs and alterations of the buildings indicate their long-term use. In terms of functionality, the buildings could have served various functions: residential, residential with household activities, storage, connected with specialized production or workshops, or they could have been used for keeping farming animals, such as cattle, sheep, and horses. In the analysis of the spatial organization of the settlement in Milejowice it was not the function that was the most significant, as it could have changed, but first of all the spatial distribution of the constructions and their relations to other structural elements of the settlement, as this helps to trace models of developmental organization. The land division map of the settlement made using the network of Thiessen polygons reveals that the spatial distribution of buildings forms the shape of a star within the following settlement complexes: $1 \mathrm{~N}, 2 \mathrm{~N}, 3 \mathrm{~N}, 1 \mathrm{~S}, 2 \mathrm{~S}$, and $3 \mathrm{~S}$ (Fig. 6-7). Complexes $1 \mathrm{~N}$ and $2 \mathrm{~N}$ were distinguished by a similar distribution of buildings, forming a square plan (Fig. 6-7). From the west, in the case of both groups of pole 
construction buildings $1 \mathrm{~N}$ and $2 \mathrm{~N}$, the longer sides of buildings were parallel to each other, while the shorter sides were facing the center (Fig. 6-7). In complex $1 \mathrm{~N}$ there were five buildings altogether, three of which were supported by 6 poles, and the other two were slightly smaller. East parts of both complexes $1 \mathrm{~N}$ and $2 \mathrm{~N}$ were characterized by a little different arrangement of buildings where longer sides were facing the center, which is completely opposite to the west part (Fig. 6-7). Complex $1 \mathrm{~N}$ is distinguished by the most densely and concisely located buildings within the whole settlement, which is indicated by the polygons with the smallest and darkest surface (Fig. 7). It is also the model of development based on the most regular and carefully planned according to an established scheme arrangement of buildings. The traces of alterations, extensions, and repairs of the buildings as well as the remains of additional construction elements, such as reinforcing ditches, indicate that the complex was used for a long time remaining in this form, closed, with fixed outline and separated from the other areas of the settlement. When it comes to orientation of buildings in complex $1 \mathrm{~N}$, the longer sides of the polygons clearly mark the directions of their spatial orientation, forming the shape of a star, in which the buildings are oriented to the outside in all directions. It should be emphasized that the buildings were directed to the outside from both the longer and shorter sides. The distribution of the polygons in complex $1 \mathrm{~N}$ reveals the intentionality of planning the space in the center, which is indicated by the regular distribution of polygons of similar size in quantile classification, placed horizontally (Fig. 7).

In the case of complex $2 \mathrm{~N}$ the spatial distribution of buildings also forms the shape of a star, which is confirmed by the orientation of longer sides of polygons that are regularly directed in different directions to the outside. Even though the structure of this complex is close to the discussed complex $1 \mathrm{~N}$, it is clearly visible in this case that the buildings are definitely more dispersed. The surface of the inner yard is also smaller than in complex $1 \mathrm{~N}$, which is surprising, when we consider the fact that the shape of the arrangement of both complexes is very similar. It seems that the discrepancy may result from the considerable proximity of complex $3 \mathrm{~N}$, separated from $2 \mathrm{~N}$ by a line of household pits, parallel to a row of buildings vertically arranged along the north-south axis, within complex 2N (Fig. 6).
Thiessen polygons indicate that both complexes perfectly complement each other and form a homogeneous spatial structure that is connected with a curved line of buildings in the central part. This is confirmed by the polygons of buildings of the same surface in the quantile classification (Fig. 7). The division into two separate complexes $2 \mathrm{~N}$ and $3 \mathrm{~N}$ seems to be in this case artificial. Most probably the complex of buildings referred to as $2 \mathrm{~N}$ appeared first. Its shape was originally very similar to complex $1 \mathrm{~N}$. However, over time it was extended to the east. The final effect of the whole structure resembles complex $1 \mathrm{~N}$ in more extended and dispersed form.

Another building complexes, marked as $1 \mathrm{~S}$ and 2S (Fig. 6) refer, when it comes to their shape, to complexes $2 \mathrm{~N}$ and $3 \mathrm{~N}$ (Fig. 6) However, the distribution of buildings is not so dense. In this case it is difficult to clearly state whether it is the original shape of the structure, or its preserved fragment. It should be emphasized that the part of the site located north-west of these complexes had been destroyed due to both natural processes and modern construction works. Nevertheless, the distribution of buildings suggests that those two complexes could have previously formed one larger building structure, similar to the earlier ones mentioned.

The last group of pole buildings within the settlement in Milejowice is the largest and the most unique in terms of the distribution of building complexes, referred to as $3 \mathrm{~S}$ (Fig. 6). Compared to other complexes, it consisted of the largest number of buildings and was also surrounded by a fence built of densely located poles. The distribution of buildings formed the shape of a circle. Within the complex, traces of alterations of buildings and fences that are directed from the outside to the inside, towards the undeveloped, empty yard, were recorded. The space of the yard is defined by three buildings, each of which determines the direction of development in the complex at the same time (Fig. 7). The structure of complex $3 \mathrm{~S}$ is star-shaped, just as in the case of the previous ones. The longer sides of the polygons are directed to the outside, which means the buildings in this complex are oriented to the outside. The original arrangement of buildings in complex $3 \mathrm{~S}$ is marked by two curved lines, along which the groups of buildings are concentrated from in the north-west and south-east (Fig. 7). Thiessen polygons for those buildings indicate the concise structure of development that is concen- 
trated around the empty space of the yard. The third axis of the arrangement of complex $3 \mathrm{~S}$ is formed by a line of pole structures, situated south-west of the largest building of the complex. This part is probably connected with the youngest phase of development of complex $3 \mathrm{~S}$, which was the result of intentional interference with its regular structure. Chronologically, it probably took place at the time when the settlement was used, when vast in-ground constructions interpreted as resource pits appeared in the south-west part of the complex (Fig. 6). It is also possible that they were related to the observed traces of alterations of the pole fencing and changes in the spatial structure of complex 3S. The increased demand for clay, used in construction works to seal the walls, can be a justification for the emergence of resource pits. The change of direction of development within the complex is evidenced mainly by the longer sides of Thiessen polygons, oriented according to the direction of distribution of buildings outside the circular fence of complex 3S (Fig. 7).

Based on analysis of the distribution of buildings within the settlement in Milejowice, one can state that the development was planned and in line with the potentially prevailing model, which involved situating buildings concentrically, forming semi-circular, circular and rounded square plans. The rule, as the map with the network of Thiessen polygons has showed, applied to each kind of construction that formed groups. In some cases the buildings were placed densely, but other ones were to a large extent dispersed, however, a regular distance between the structures was always kept (Fig. 7). A certain rule also applies to single objects placed in different parts of the settlement, most often on its peripheries and at some distance from the densely built-up areas. However, their character is completely peripheral in reference to the dominating concise structure of the settlement in Milejowice.

Trying to reconstruct the way social life in the settlement of Milejowice was organized, on the basis of the preserved and available for archaeological research spatial arrangement models (in this case, buildings as the most important elements of the settlement's structure), one can conclude that each of the distinguished complexes was inhabited by a separate group of people. Significant similarities in the distribution of buildings within each complex indicate that there was a uniform model of spatial organization. This concerned both the size of pole buildings and the way they were arranged according to a precisely defined plan. Despite minor differences in the general outline of the distinguished complexes, one can clearly see that all of them represent one model of spatial organization within the settlement. Such a unification among small societies located in particular complexes seems to indicate balanced positions in the social hierarchy of the settlement in Milejowice, however, the size, number of buildings, traces of long-term residence and re-organization of the structure within complex $3 \mathrm{~S}$, lead to a reflection that the group that inhabited this part of the settlement could have been somehow privileged.

Further analyses presented in this article were focused on the study of functions of the distinguished complexes and economic zones of the settlement in Milejowice, roughly defined by E. Bugaj and J. Kopiasz (Bugaj, Kopiasz 2008). The main goal was the attempt at answering the questions: do the activities that took place in the aboveground building complexes clearly indicate their similar functional role in the settlement's structure, or maybe each complex was different in that matter? Moreover, attention was also paid to defining the role of the largest complex referred to as $3 \mathrm{~S}$ in the organization of the settlement and its functional relations to the features located in the distinguished economic zones (Fig. 8). That is why we carried out an analysis of the distribution of particular functional categories of features in the areas determined by Thiessen polygons for each building type and an analysis of location of selected types of tools in all objects (Fig. 8). The study allowed us to define what functional types of features were located within an area determined by a Thiessen polygon, which at the same time was the closest vicinity of an aboveground building. In the interpretation of the functional role of the features we also used choropleth maps presenting spatial distribution of ceramic finds, including painted pottery, bones and burnt clay, found in the features and cultural layer (Fig. 8, 10, 12).

Based on observations of the distribution of in-ground features and tools within complex $1 \mathrm{~N}$, it can be stated that inside some buildings there were storage pits that probably served as cellars. Other buildings in the area of their polygons had a few features whose functions could not be precisely defined. In two cases the presence of bone tools and stone grinders in the fill of in-ground features was 
recorded, which can confirm their household utilitarian function. The largest group of tools, in this case stone grinders, was discovered in the biggest building of complex $1 \mathrm{~N}$. Close to that building there was also a feature of a ritual character, interpreted as a votive pit with a deposit. In the south part of the complex there was also a concentration of in-ground features together with a well. In one of the pits a bone tool was found. This group should be associated with the south line of pole buildings, however, the well seems to have belonged to the whole 1N complex (Fig. 8). When it comes to the distribution of mass ceramic finds, including painted pottery fragments, it can be stated that the largest concentrations were found in the north part of complex $1 \mathrm{~N}$, in the vicinity of the biggest building (Fig. 10). In the case of bones, they were evenly distributed in both the features and cultural layer within the whole area of complex $1 \mathrm{~N}$. Burnt clay was recorded in one place near the well, where it was probably used as a construction material (Fig. 12). In an attempt at a functional interpretation of complex $1 \mathrm{~N}$, one can assume that in this part of the settlement was a small group of people who were involved in a kind of household economic activity connected with the production and processing of food for their own needs. The even distribution of pottery indicate that most of the buildings were inhabited. Some of the objects could have served residential and economic functions. Very interesting is the question of the role of the largest building where the votive pit was situated. Its size and the presence of a feature connected with ceremonial practices compels us to recognize its distinctive function within complex $1 \mathrm{~N}$. The range of types of mass material and three stone grinders discovered inside the building may suggest that its function was not clear. It could have been the seat of the most significant member of the society, however, the practical residential and economic functions of the building cannot be excluded.

In the case of complexes $2 \mathrm{~N}$ and $3 \mathrm{~N}$ a similar arrangement of pits in relation to the buildings can be observed (Fig. 6). In-ground features were located in the close vicinity of buildings, just like in the above discussed complex $1 \mathrm{~N}$. Only in one building was there an inner storage pit which served as a cellar. The distribution of tools in features, similar as in the case of complex $1 \mathrm{~N}$, reveals that general activities within the occupied surface included living and household food production. Most pits that were present in a close vicinity to the buildings could have served different functions connected with storing food products or production of tools or pottery. The distribution of pottery and bone artifacts (Fig. 10, 12) indicate that the whole surface of both complexes was intensively used for residential and economic purposes, and the economic activity had a kind of backyard character, focused on the current needs of the group of people who inhabited complexes $2 \mathrm{~N}$ and $3 \mathrm{~N}$. No fixed model of planning in-ground features in relation to pole buildings was observed. It seems that they were emerging over the period in which the settlement existed to cater for current needs. The largest concentration of mass material can be noticed in the central part that links both complexes, along the line of buildings situated vertically along the north-south axis where vast resource pits were located. In the features and cultural layer large amounts of mass bone artifacts were found. In this zone one of three wells that were discovered within the discussed complexes was also located. Moreover, in the inground features bone and stone tools were recorded (Fig 12). The interpretation of this part of building complexes as an internal zone of purely economic character seems legitimate. It is worth adding that in one of the pits a large flat erratic boulder was placed which could have served practical economic functions, however it is possible that it was used in other ways, which had been already mentioned in this article (Bugaj, Gediga 2004, 224).

In the other distinguished building complexes, referred to as $1 \mathrm{~S}$ and $2 \mathrm{~S}$, the presence of structures that could have served different functions, not only residential purposes, is rather limited comparing to those above discussed. In both complexes the buildings were dispersed and less regular than in complexes $1 \mathrm{~N}$ and $2 \mathrm{~N}$. In the group marked as $1 \mathrm{~S}$ in-ground features of typically utilitarian character were relatively rare, while in the west part of the complex there were more features interpreted as dugouts (Fig. 6). Such a functional interpretation was dictated first of all by the size and shape, characteristic of dugouts. It must be emphasized that their function could have been differentiated. The distribution of bone and stone tools (Fig. 8), as well as mass ceramic and bone finds (Fig. 10,12) indicate that this part was probably occupied by productionrelated activities, while the area with pole construction buildings was used for residential purposes and presumably for keeping animals as well. 
In the second building complex that was recorded in the south part of the settlement in Milejowice, marked as $2 \mathrm{~S}$, a visible concentration of pits can be observed. They shape a semi-circle surrounding the buildings from the inner side (Fig. 6). Most of them were located within the reach of the polygon that belonged to the building situated right in the center of the complex (Fig. 8). In terms of function, the features can be interpreted as traces of backyard production and storage of food. In the fills numerous fragments of mass ceramic and bone material were recorded (Fig. 10, 12). In both complexes, $2 \mathrm{~S}$ and the already discussed $1 \mathrm{~S}$ no traces of wells were recorded, which is a distinctive feature of this complex, compared to other ones: $1 \mathrm{~N}, 2 \mathrm{~N}$, $3 \mathrm{~N}$ and $3 \mathrm{~S}$ (Fig. 6).

The last element of development consisting of densely distributed aboveground buildings that was organized according to specified standards concerning the structure of spatial planning, is a building complex referred to as $3 \mathrm{~S}$. Compared to other groups of aboveground buildings at the settlement in Milejowice, this one is characteristic not only due to its irregular circular shape, defined by the distribution of buildings and a regular pole fencing, which was not recorded in any other complex, but also the largest area and the highest number of aboveground and in-ground features (Fig. 1, 6). All premises lead to a reflection on the special role of complex $3 \mathrm{~S}$ in the settlement's structure, not only in a spatial sense, but also as an indicator of a differentiated social organization.

Also when it comes to the number and quality of tools and mass material, complex $3 \mathrm{~S}$ appears especially rich compared to other groups of aboveground buildings (Fig. 8, 10,12). The largest collection of bronze items was discovered there as well. Those were probably fragments of bronze jewelry or wires. They were found in features interpreted as dugouts, often together with other objects, such as bone tools (Fig. 8).

The largest concentration of bone, stone, and bronze objects was observed in the north-west part of complex 3S. In the case of distribution of ceramic artifacts, including painted pottery, the main concentration was also in the same place (Fig. 8, $10,12)$. It may be the evidence of the intense use of this part of the complex and also indicate various relocations of artifacts which can be connected with locating dugouts in the place where aboveground buildings had been situated earlier. In one of the buildings located in the discussed part of the complex, stone grinders were found (Fig. 8). In the outline of the construction traces of a reinforcing ditch were recorded. An analogous building was discovered in complex $1 \mathrm{~N}$.

The second concentration of finds was visible in the south part of the discussed building complex, at the largest building. Above all, bone tools, minor bronze items of undefined function, painted and graphite pottery were found (Fig. 8, 10). However, it should be emphasized that within the largest building no artifacts were identified (Fig. 8, 10, 12). What is characteristic of the discussed $3 \mathrm{~S}$ complex, compared to the other ones, is that as many as four votive deposits were discovered within its area. They were found in the central part of complex $3 \mathrm{~S}$, in the empty yard and also at the outer fence, in the south and south-east part of the complex (Bugaj, Gediga 2004, 227, fig. 15 and 20-21). In the case of complex $1 \mathrm{~N}$ only one feature of that kind was recorded (Fig. 6).

The largest building in complex $3 \mathrm{~S}$ covered ca. $142.5 \mathrm{~m}^{2}$ and was erected using construction made of several dozen wooden poles arranged in rows. The arrangement of the poles may indicate that inner divisions or arcades existed there (Bugaj, Kopiasz 2006, 196, fig. 10). Such features as the impressive size of the building, its location in the central part of complex 3S, and the proximity of votive objects have led the scholars to the interpretation that this building could have been a seat of a prominent member of society, a representative of the local aristocracy, or alternatively the community's assembly hall (Bugaj, Kopiasz 2006, 196).

Traces of intensive use of the north-west part of complex $3 \mathrm{~S}$ can be directly connected with numerous construction works, including alterations of aboveground buildings and moving the outer pole fence to the inside. In this part the frequency of finds of mass material and tools is very low (Fig. 8-9).

When comparing the spatial and functional structure of the discussed complex $3 \mathrm{~S}$ to its smaller equivalents located further north, its accentuated position within the area of the whole settlement can be noticed. This applies to the size of buildings, distribution of features and their number, the presence of pole fences which was not recorded in any other complex, and also the occurrence of artifacts of different material and functional categories. Trying to interpret the role of this part of the 


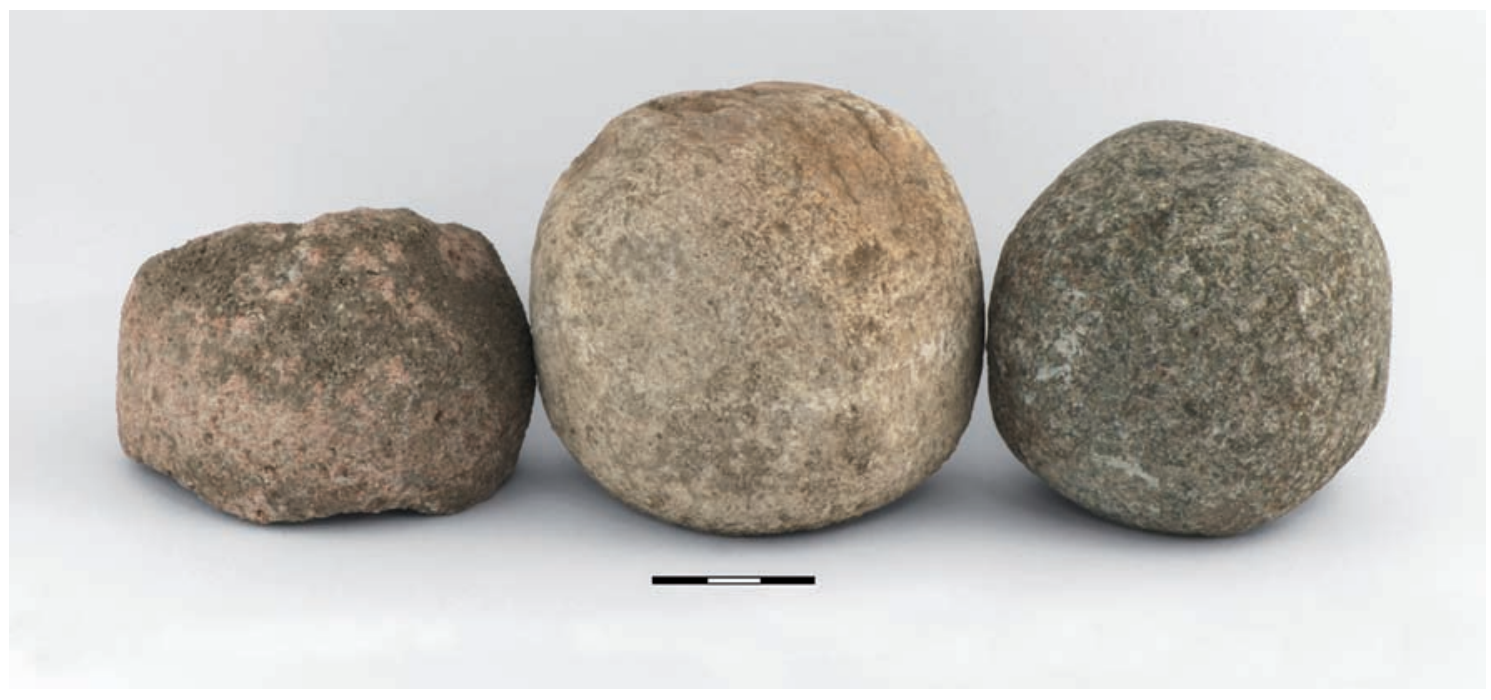

Fig. 9. Stone tools - grinders from feature no. 333 in Milejowice 19 (by I. Dolata-Daszkiewicz)

settlement in Milejowice, it seems most likely that it mainly served residential functions with household production. This is indicated by tools used in everyday activities related to preparing and processing food, such as stone grinders, smoothing files, bone tools, ceramic vessels, etc. Nevertheless, remarkably more bronze items were recorded here than in other complexes. These were mainly fragments of minor decorations made of a wire. Also, the largest share of painted and graphite pottery was recorded in this area (Kopiasz 2008, 214-215; Fig. 10). Another characteristic feature of this complex is the presence of distinguished economic zones, located west and east of the circular fence (Fig. 6). On the west side there were various typically utilitarian features, including resource pits, storage pits, and other pits whose function cannot be precisely determined. All features were situated in the vicinity of one pole construction building (Fig. 6-7). In this part of the settlement low number of ceramic items and tools was observed, while in features and cultural layer those were mainly bone artifacts of mass character. This indicates a function connected with storing different products and acquisition of raw materials. As the geomorphological analyses and boreholes done at the site reveal, natural resources are the most abundant there (Fig. 4). It is also stated that two features most probably interpreted as wells were located in this part of the settlement. It should be emphasized that, unlike in the case of the other five wells discovered in Milejowice (Fig. 6), the function of these features is not that clear.
The second economic zone which was probably functionally connected with complex $3 \mathrm{~S}$ is formed by the area where a line of pits and a metallurgic workshop was located (Fig. 6). In the horizontal plan of the building traces of a storage pit, presumably used as a cellar, were recorded. Apart from that, no other mass material or tools were found. In the vicinity of the building, from the south-east, where the row of storage pits was located, several bone tools, a loom weight, minor bronze items of unspecified utilitarian function and a stone grinder were discovered (Fig. 8). It seems likely that the pits served various functions related to household activities. They were spatially connected with the building around which they were concentrated. From the north-west side of the building a metallurgic workshop formed by a complex of pits was located (Fig. 8). The function of the structure was defined already during the preliminary source analysis, during which numerous fragments of bronze raw material, casting moulds, production waste, and finished products in the form of bronze knobs, rein-knobs and applications, including decorations of horse riding equipment (Fig. 11) that had been found in the layers, were associated with a craftsman's workshop (Bugaj et al. 2002, fig. 6.9-11; Bugaj, Gediga, 2004, 228, fig. 14.7). Such an interpretation is confirmed by the distribution of clay casting moulds, stone smoothing tools, bone tools, and the already mentioned bronze items (Fig. 8). Moreover, mass bone material and small fragments of painted pottery (Fig. 8, 10, 12) were found. Their 


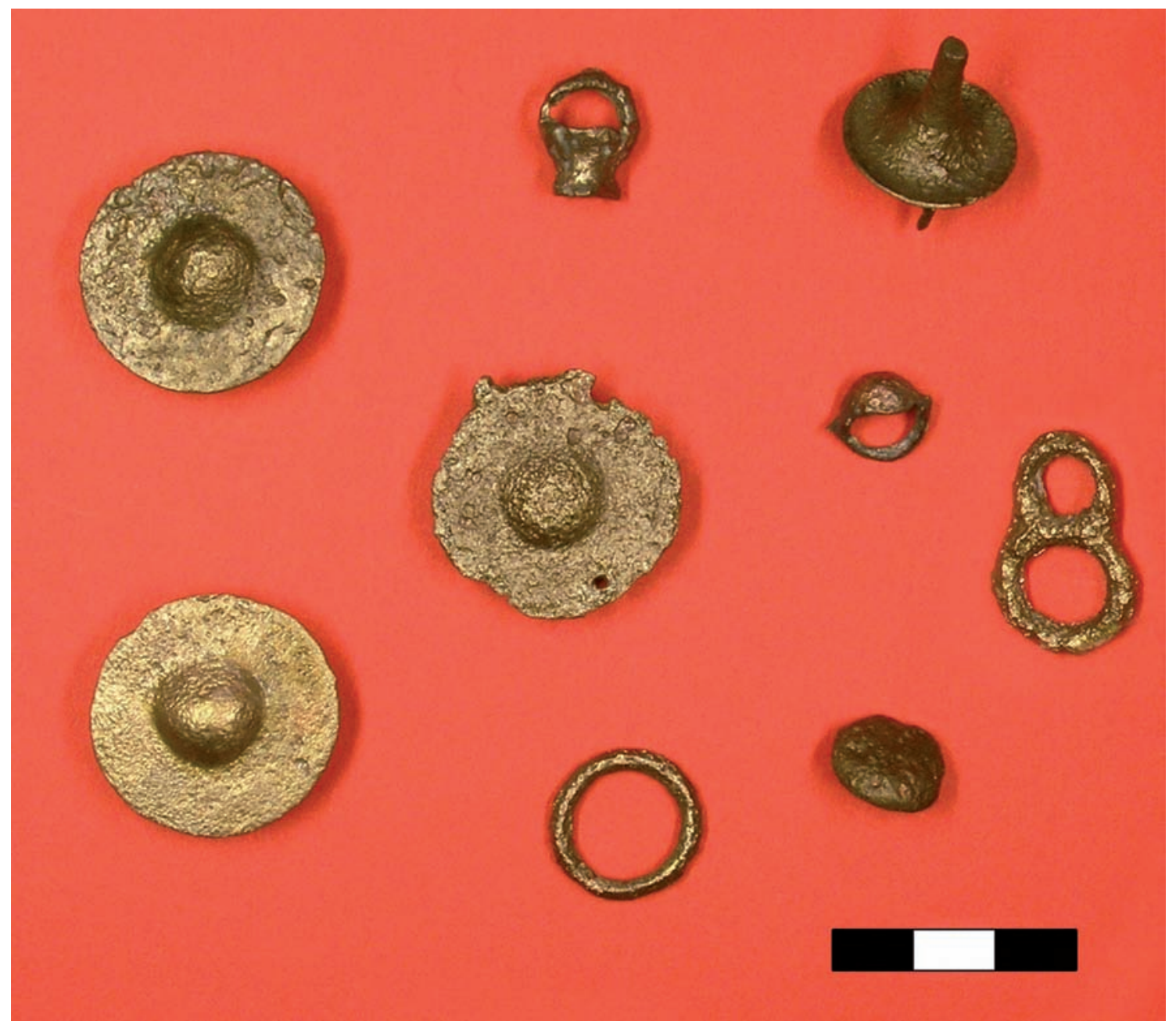

Fig. 11. Bronze objects from the "metallurgic workshop" (by I. Dolata-Daszkiewicz)

presence, just as in the case of many other features within the settlement, may have resulted from different kinds of post-depositional processes. Functionally, the bronze workshop most probably served the needs of the community that inhabited complex $3 \mathrm{~S}$ as well as the residents of other parts of the settlement.

The presence of various crafts workshops, often highly specialized, in the area of Hallstatt settlements was a common phenomenon in the Early Iron Age. In Heuneburg, located on the Danube, the existence of production workshops connected with bronze and iron metallurgy and also bone, antler, glass, and lignite processing, were located close to the buildings or outside the complexes, in separated for this purpose production zones (Schlette 1984, 31-32). The location of the metallurgy workshop and utilitarian features in separate parts of the settlement, outside the fenced complex $3 \mathrm{~S}$ in Mile- jowice (Fig. 6), refers to the zonal division of the Hallstatt settlement in Heuneburg.

The conclusions drawn from the macro- and microscopic traseological analyses performed for most of the stone and bone tools found in the features and cultural layers proved very important in the studies on the function of particular features and their concentrations that formed separate complexes in the settlement in Milejowice (Kufel-Diakowska 2019; Diakowski 2019). The analyses were carried out in order to determine the way each item was used in everyday activities of the settlement's population. Some objects that were initially classified as tools were disqualified in that category due to the lack of traces of intentional processing. In the case of other ones the presence of "working surfaces" indicating various forms of use was identified, which makes it difficult to precisely define the function of the items. Most likely, the range of possibilities 


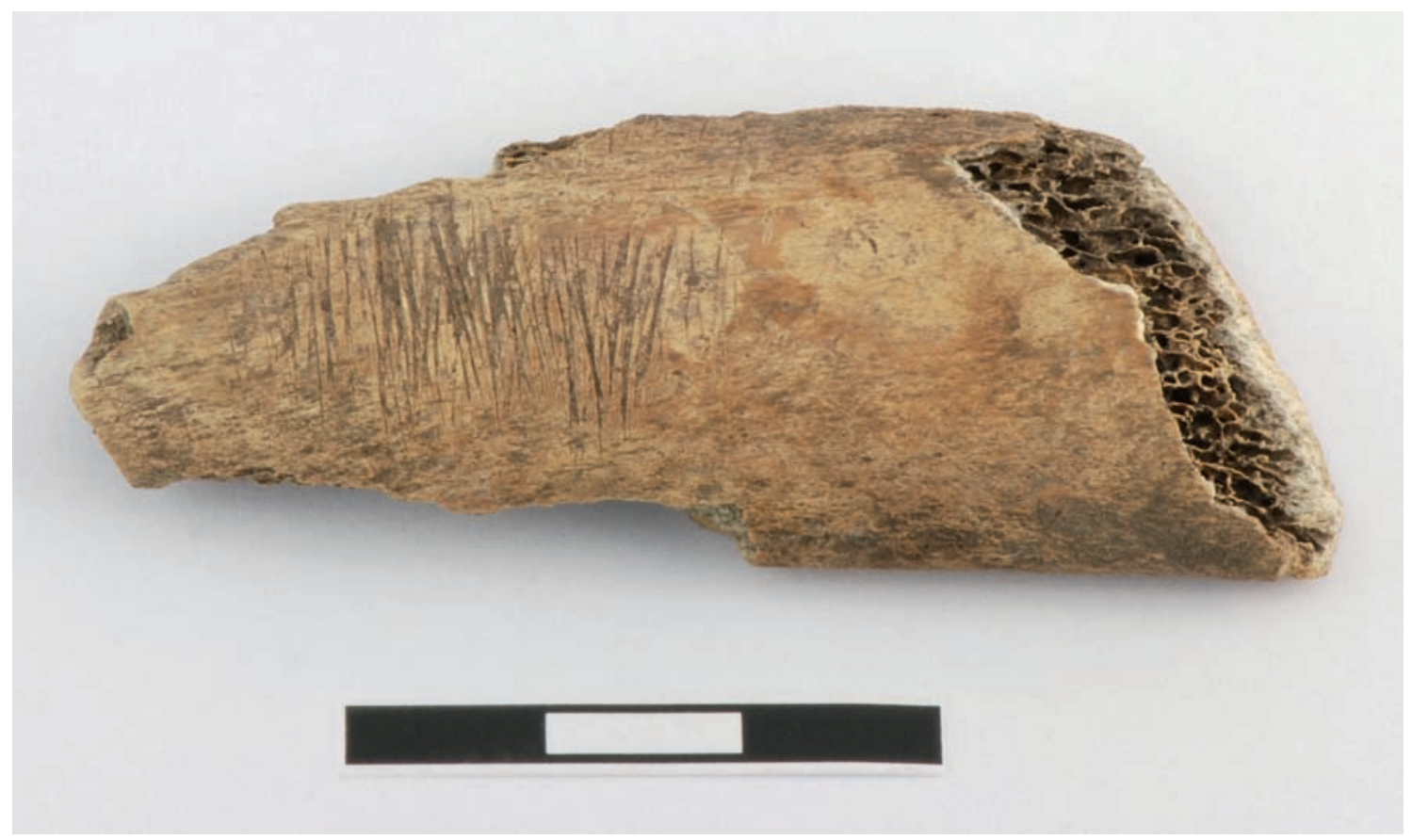

Fig. 13. Bone tool with traces of use from one of the dug-out huts in Milejowice 19 (by I. Dolata-Daszkiewicz)

of their use was connected with food processing, including grinding, and also production of pottery, i.e., preparing ceramic paste, polishing the surface vessels or forming the surface and edges of other tools, e.g., made of bone (Fig. 9, 13).

Environmental factors, discussed earlier, also played an important role in the spatial and functional organization of the settlement in Milejowice. All those factors surely determined the value of the occupied space and enabled organizing it in unlimited ways at the same time. Favorable terrain relief with no considerable altitude differentiation (Fig. 3), which, as lithological profiles have revealed (Fig. 4), has not remarkably changed since prehistory, allowed for good visibility within the whole area of the settlement and even insolation in all of its parts, considering the actual climate conditions. All of those aspects could have influenced the rapid spatial development of the settlement in all directions, as there were practically no natural obstacles. The high level of groundwater enabled locating wells in any place, minimizing the distance to sources of water, which was actually easily accessible in the close vicinity of the settlement. Excellent quality chernozems that occur in the whole area of the discussed settlement could have been a good basis for food production. The presence of mineral resources and wood that were certainly used in advanced construction works and economic activity was also significant.

\section{SOCIAL ASPECTS OF SPATIAL ORGANIZATION OF THE SETTLEMENT IN MILEJOWICE}

The interpretation of the space of the settlement in Milejowice in terms of social stratification of the population that inhabited it raises various problems, mainly due to the lack of a full spectrum of information that could lead to clear-cut conclusions in that matter. The conclusions presented above can be repeated, i.e., the complexes of buildings distinguished within the site's area were probably inhabited by separate groups of people, presumably relatives, however, it is difficult to precisely determine to what extent they were coherent or stratified. Significant similarities in the distribution of buildings within each complex suggest that there was one model for spatial organization. Such a unification of development among separate small communities settled in each complex seem to indicate balanced positions in the social hierarchy of the settlement's inhabitants. Nevertheless, it must be noticed that 
the size of complex 3S in Milejowice, the number of buildings, the traces of long-term use of this part of the settlement and the re-organization of development within its area, evident circular fences (Fig. 1) and first of all, the most considerable quantity and quality differentiation of tools and concentration of ceramic artifacts, found mostly in the inground features and to lower extent within buildings, support the earlier presented interpretations that indicate the privileged role of the community that inhabited this very part of the settlement (see also: Fig. 6, 8, 10).

In one of the earlier works concerning the settlement in Milejowice, J. Kopiasz presented the results of the studies on ceramics, a rich and differentiated category of sources. He focused his attention on the group of finds that he referred to as "prestigious" or "luxurious" pottery (Kopiasz 2008, 215). As "prestigious" or "luxurious" pottery he perceived the category of vase-shaped vessels with a funnel-shaped mouth and a conical neck, dated to Hallstatt C. The vessels are characterized by high quality production and proper firing, thanks to which containers of blackened and polished outer surface were obtained. They were decorated with diagonal, vertical or horizontal grooves or lines, and sometimes also conical knobs. Moreover, the scholar also included painted pottery in the group of "prestigious" vessels. In his opinion, this could have served as a kind of "equivalent" goods of luxurious character for the population of the settlement in Milejowice, just like graphite vessels with characteristically polished, metallic outer surface (Kopiasz 2008, 215-216, fig. 4-7). The last category of ceramic finds not always can be undoubtedly distinguished due to the usually fragmentary state of preservation of vessels that are found at settlement sites and the high degree of erosion. Nonetheless, the settlement in Milejowice site 19, based on the ceramic finds, including those distinguished as "prestigious" sources, appears to be a place once inhabited by a relatively rich population, in comparison to the so-called Lusatian settlements known from this region, generally poorly recognized, unlike the cemeteries.

It should be mentioned that the south part of the site of Milejowice 19 with complex 3S was compared in earlier works to the seats of an "aristocratic" social group or sometimes to the structures referred to as "Herrensitz" (Bugaj, Gediga 2004; Bugaj, Kopiasz 2006; Bugaj, Kopiasz 2008; Kopiasz 2008).
In light of the source data obtained during research on the settlement in Milejowice and the presented spatial analyses of its structure, such an opinion, moderately or strongly criticized (Dzięgielewski 2010, 89; Baron et al. 2011, 353-355), appears as an interpretation that requires some correction, yet not rejection. The Hallstatt "manors" are usually far more monumental and more abundant in finds of prestigious items, often imported, and their fences are usually basically fortifications, which does not apply to the fences discovered in Milejowice ${ }^{2}$. Nevertheless, it is worth noting that the most external and the next inner lines of circular fences in this part of the settlement were based on solid poles, relatively densely placed - from $0.6 \mathrm{~m}$ to $1.8 \mathrm{~m}$ from one another (Bugaj, Kopiasz 2006, 193) and their far from lightweight wattle fences.

Referring in the previous studies to the seats of the "Herrensitz" type as an analogy to the circular structure from Milejowice was a result of noticing in the Early Iron Age in the vast areas of Central and Western Europe a kind of supraregional rule that determined a repetitive model of arranging a settlement within an area limited by ditches and/ or palisades, which was implemented at particular sites to a different extent and on a various scale (Gralak 2013, 339 with further literature). However, the model definitely reached the south-west part of present-day Poland. In reference to Milejowice this meant referring to a defined rule or practice of separating a dwelling by a certain group of people, resulting from their hypothetical higher social and economic status, not seeing strict morphological analogies between the Lower Silesian site and those known from the West-Hallstatt zone. It is also worth mentioning that the problem of interpreting the "Herrensitz" type of structures in the vast areas

2 It must be noticed that in the works by E. Bugaj as an author or co-author concerning Milejowice there were no mentions about "fortifying" the south complex of the settlement, separated by circular fences, which was supposed to have led to giving it a defensive character, while such unjustified statements are put forward by the authors of the article on Zabrodzie (Baron et al. 2011, 354). The quoted fragment (Bugaj, Kopiasz 2006, 200) goes as follows: "Everything suggests that it was an inhabited yet intentionally separated part of the settlement. We believe that distinguishing it was not of practical or defensive character yet it was a symbolic act, connected with the high social and probably also economic status of the inhabitants of this part of settlement". 
of western Europe is an open issue and scholars do not fully agree in the source literature concerning their significance and function, and particular examples of such sites are often analyzed individually, despite numerous attempts to synthesize the subject (see also: e.g., Kas, Schußmann 1998, 101106; Rieckhoff, Biel 2001, 113-119).

We believe that in the case of the site of Milejowice 19, despite the lack of close formal analogies to the settlements of the "Herrensitz" type, the functional and spatial structure, and first of all the remarkable $3 \mathrm{~S}$ complex, should be regarded as reasons to include the settlement in the spectrum of cultural and social changes connected with the emergence of the elites in the south-west part of present-day Poland. We are not convinced of the purely practical aspect of erecting palisade fences in the settlements suggested by some scholars as well as referring to an analogy from the Scandinavian context, in which the cultural environment was experiencing a different rhythm of changes than can be observed in Lower Silesia (Baron et al. 2010, 338-340). In our opinion it is more justified to state that it is the larger population that occupied this part of the settlement who were involved in more intensive and more specialized crafts-based production, and therefore growing rich faster and having a bigger share in exchange of goods and the possibility of their distribution that can be the evidence of the ongoing hierarchization of the society, the main manifestation of which would be the part of the site separated by circular fences. Very important is also the fact that in this area of the settlement relatively more traces of ritual activities in the form of four votive deposits had been discovered (Bugaj, Gediga 2004, 227, fig. 15 and 20-21). Referring these findings to the outline of the most significant forms of conceptualization of processes that lead to the emergence and institutionalization of social inequities in archaeology, including social integration, the emergence of specialized crafts-based production and exchange, and also organized ceremonial practices (Marciniak, Tabaczyński 2017, 47), one can confirm the presence of such processes concerning the settlement in Milejowice.
Interesting observations were made by Peter Trebsche (2010), based on sociological theories, especially the sociology of architecture and the use of examples of buildings from the stronghold in Biskupin on the one hand and from the settlement in Milejowice on the other. He claims that the building development in Biskupin induces us to perceive the community that inhabited the stronghold as egalitarian, acting mainly collectively or "corporationally", while in the case of Milejowice the society appears to have been divided into smaller groups, more individual and hierarchized, acting as a network (Trebsche 2010, 159-163).

However, we should interpret the settlement in Milejowice first of all in the wider context of changes that took place in the Hallstatt Period in Lower Silesia. Considering the cultural context embracing the Wrocław Plain in the Early Iron Age and the results of other large-scale excavations that resulted in discoveries of further remarkable sites, such as the cemetery in Domasław, Wrocław district, the settlement in Milejowice can be perceived as a place that confirmed the presence of people who were influenced by the impulses from the Alpine zone of the Hallstatt culture and implementing cultural models adopted from that area. The issues were comprehensively discussed many times in the past years in the works of B. Gediga $(2011 ; 2013)$, in which he suggested the necessity to revise our knowledge on the society of the Lusatian culture inhabiting on the one hand the south-west part of present-day Poland - and on the other, the areas in Cuyavia where its settlements, yet representing a different model of cultural development, emerged. In light of discoveries connected with excavations that covered large areas and were carried out due to road construction, including the cemetery in Domasław as well as the settlements in Milejowice or Stary Śleszów, he advocates the concept of recognizing the areas of south-western Poland as a province of the Hallstatt culture (Gediga 2010, 211-213; 2011, 90-111, fig. 117; Gediga 2013, 393-397, fig. 1). We find these views convincing and that the settlement in Milejowice site 19 can be treated as the Lower Silesian variant of this supraregional and locally differentiated cultural phenomenon. 


\section{BIBLIOGRAPHY}

Baron J., Golański A., Schellner K. (2011). Problems of Interpretation of Early Iron Age Fenced Settlements. A Case Study of Site 8 from Zabrodzie, Wrocław District. Sprawozdania Archeologiczne, 63, 319-359.

Buchner A. (2013). Zastosowanie Systemów Informacji Geograficznej (GIS) w badaniu struktury przestrzennej osady kultury łużyckiej na stanowisku Stary Śleszów 17, pow. wrocławski. In: J. Kolenda, A. Mierzwiński, S. Moździoch, L. Żygadło (eds), Z badań nad kultura społeczeństw pradziejowych $i$ wczesnośredniowiecznych. Ksiega Jubileuszowa dedykowana Profesorowi Bogusławowi Gedidze w osiemdziesiąta rocznice urodzin przez przyjaciól, kolegów i uczniów (787-794). Wrocław: Instytut Archeologii i Etnologii PAN, Ośrodek Badań nad Kulturą Późnego Antyku i Wczesnego Średniowiecza.

Buchner A. (2018). Struktura przestrzenno-funkcjonalna osady z wczesnej epoki żelaza w Starym Śleszowie, pow. wrocławski. Ślaskie Sprawozdania Archeologiczne, 60(1), 365-381.

Bugaj E., Gediga B., Kosicki A., Szwed R., Żygadło L. (2002). Badania ratownicze na stanowisku Milejowice, pow. Wrocław w latach 1999-2001. Śląskie Sprawozdania Archeologiczne, 44, 235-251.

Bugaj E., Gediga B. (2004). Wyniki ratowniczych badań wykopaliskowych przeprowadzonych na stanowisku Milejowice 19, gm. Żórawina, pow. Wrocław, woj. dolnośląskie. In: Raport 2001-2002. Wstepne wyniki konserwatorskich badań archeologicznych $w$ strefie budowy autostrad w Polsce za lata 2001-2002. Zeszyty Ośrodka Ochrony Dziedzictwa Archeologicznego (d. Zeszyty ORBA) (216-233). Warszawa: Ośrodek Ochrony Dziedzictwa Archeologicznego.

Bugaj E., Kopiasz J. (2006). Próba interpretacji zabudowy osady z wczesnej epoki żelaza na stanowisku Milejowice 19, pow. wrocławski. In: B. Gediga, W. Piotrowski (eds), Architektura $i$ budownictwo epoki brąu $i$ wczesnych okresów epoki żelaza. Problemy rekonstrukcji (175-207). Biskupin-Wrocław: Polska Akademia Nauk, Oddział we Wrocławiu, Muzeum Archeologiczne w Biskupinie, IAiE PAN.

Bugaj E., Kopiasz J. (2008). The Early Iron Age Elite and Their Seat in the South West Poland. A Case Study of the Milejowice Site 19, Wrocław District. Przeglad Archeologiczny, 56, 101-115.

Butent-Stefaniak B. (1997). Z badań nad stosunkami kulturowymi $w$ dorzeczu górnej i środkowej Odry we wczesnym okresie epoki brąu. Wrocław-WarszawaKraków: Ossolineum.

Ciesielska A. (2001). Koncepcje grup społecznych i sposoby ich badania w archeologii procesualnej, postprocesualnej i neomarksistowskiej. Przegląd Archeologiczny, 49, 5-15.

Chmal H., Traczyk A. 2001. Charakterystyka geomorfologiczno-geologiczna stanowisk archeologicznych przy budowanej autostradzie A-4 (rekonstrukcja krajobrazów pradziejowych i średniowiecznych Równiny Wrocławskiej). Wrocław: Archiwum IAiE PAN, Ośrodek Badań nad Kulturą Późnego Antyku i Wczesnego Średniowiecza we Wrocławiu (maszynopis).

David B., Thomas J. (2008). Landscape Archaeology: Introduction. In: B. David, J. Thomas (eds), Handbook of Landscape Archaeology (27-43). Walnut Creek, CA: Left Coast Press, Inc.

Diakowski M. 2019. Raport z analizy traseologicznej przedmiotów kościanych ze stanowiska Milejowice 19, pow. wrocławski. Wrocław: Archiwum IAiE PAN, Ośrodek Badań nad Kulturą Późnego Antyku i Wczesnego Średniowiecza we Wrocławiu (maszynopis).

Dzięgielewski K. 2010. Osada z młodszej i późnej epoki brązu na stanowisku 48 w Wojniczu, pow. Tarnów. In: J. Chochorowski (ed.), Via Archaeologica. Źródła z badań wykopaliskowych na trasie autostrady A4 $w$ Małopolsce (55-116). Kraków: Instytut Archeologii UJ, Instytut Archeologii i Etnologii PAN, Muzeum Archeologiczne w Krakowie.

Gediga B. (2004). Problemy socjotopografii osad ludności kultury łużyckiej. In: E. Kazdová, Z. Měřínský, K. Šabatová (eds), K poctě Vladimíru Podborskému. Přátelé a žáci k sedmdesátým narozeninám (409-418). Brno: Masarykova univerzita v Brně.

Gediga B. (2010). Śląsk - regionalna prowincja kultury halsztackiej. In: B. Gediga, W. Piotrowski (eds), Rola głównych centrów kulturowych $w$ kształtowaniu oblicza kulturowego Europy Środkowej we wczesnych okresach epoki żelaza (187-218). Biskupin-Wrocław: Muzeum Archeologiczne w Biskupinie, Polska Akademia Nauk - Oddział we Wrocławiu, IAiE PAN.

Gediga B. (2011). Neue Forschungen zu den früheisenzeitlichen Kulturen in Südwestpolen. Acta Archaeologica Carpathica, 66, 83-116.

Gediga B. (2013). The Culture of the Early Iron Age in the South-Western Regions of Poland in the Light of New Research. In: S. Bergerbrant, S. Sabatini (eds), 
Counterpoint: Essays in Archaeology and Heritage Studies in Honour of Professor Kristian Kristiansen (383-399). Oxford: Archeopress.

Goslar T. 2004. Raport z wykonania datowań C-14 w Poznańskim Laboratorium Radiowęglowym. Numer pracy: 673/04. Poznań: Archiwum IAiE PAN, Ośrodek Badań nad Kulturą Późnego Antyku i Wczesnego Średniowiecza we Wrocławiu (maszynopis).

Goslar T. 2006. Raport z wykonania datowań C-14 w Poznańskim Laboratorium Radiowęglowym. Numer pracy: 1351/05. Poznań: Archiwum IAiE PAN, Ośrodek Badań nad Kulturą Późnego Antyku i Wczesnego Średniowiecza we Wrocławiu (maszynopis).

Goslar T. 2019. Raport z wykonania datowań C-14 w Poznańskim Laboratorium Radiowęglowym. Numer pracy: 14866/19. Poznań: Archiwum IAiE PAN, Ośrodek Badań nad Kulturą Późnego Antyku i Wczesnego Średniowiecza we Wrocławiu (maszynopis).

Gralak T. (2013). Budownictwo i styl w okresie halsztackim C na Dolnym Śląsku. In: J. Kolenda, A. Mierzwiński, S. Moździoch, L. Żygadło (eds), Z badań nad kultura społeczeństw pradziejowych $i$ wczesnośredniowiecznych. Księga Jubileuszowa dedykowana Profesorowi Bogusławowi Gedidze w osiemdziesiąta rocznice urodzin przez przyjaciót, kolegów i uczniów (329-347). Wrocław: Instytut Archeologii i Etnologii PAN, Ośrodek Badań nad Kulturą Późnego Antyku i Wczesnego Średniowiecza.

Kadrow S. (1991). Iwanowice. Stanowisko Babia Góra, cz. I. Rozwój przestrzenny osady z wczesnego okresu epoki brązu. Kraków: Instytut Historii Kultury Materialnej Polskiej Akademii Nauk.

Kas S., Schußmann M. (1998). Einige Überlegungen zu den hallstattzeitlichen Herrenhöfen. In: B. Berthold, E. Kahler, S. Kas, D. Neubauer, S. Schmidt, M. Schußmann (eds), Zeitenblicke. Ehrengabe für Walter Janssen (93-123). Rahden: Marie Leidorf.

Kobyliński Z. (1988). Struktury osadnicze na ziemiach polskich u schytku starożytności $i$ w początkach wczesnego średniowiecza. Wrocław: Zakład Narodowy imienia Ossolińskich. Wydawnictwo Polskiej Akademii Nauk.

Kopiasz J. (2004). Cmentarzysko kultury unietyckiej na stanowisku Milejowice 19, powiat Wrocław, woj. dolnośląskie. In: Archeologiczne Zeszyty Autostradowe Instytutu Archeologii $i$ Etnologii PAN, z. 3. Badania na autostradzie A-4, cz. II (31-60). Wrocław: Zespół Badań Ratowniczych Instytutu Archeologii i Etnologii PAN Oddział we Wrocławiu.

Kopiasz J. (2007). Próba omówienia zagadnień socjotopograficznych w kontekście analiz statystycznych wy- branej ceramiki „luksusowej” na przykładzie dwóch stanowisk z okresu halsztackiego C: Milejowice 19 i Stary Śleszów 17, powiat Wrocław. In: L. Bakalarska (ed.), Materiaty z konferencji konserwatorstwa archeologicznego Jurata (8-20 V 2005 r.) Wigry (28-30 IX 2005 r.) Krynica (30 XI - 3 XII 2005 r.) (195-210). Warszawa: Narodowy Instytut Dziedzictwa.

Kopiasz J. (2008). Ceramika „prestiżowa” jako wyraz struktury społecznej mieszkańców osady z okresu halsztackiego $\mathrm{C}$ w Milejowicach, pow. Wrocław. In: B. Gediga, W. Piotrowski (ed.), Sztuka pradziejowa i wczesnośredniowieczna jako źródło historyczne (211228). Biskupin-Wrocław: Muzeum Archeologiczne w Biskupinie, Komisja Archeologiczna Wrocławskiego Oddziału PAN, IAiE PAN.

Krąpiec M. 2001a. Badania dendrochronologiczne prób drewna pozyskanych z prac archeologicznych związanych z budową autostrady A-4 ze stanowiska Milejowice 19 (ob. 53 i 280). Kraków: Archiwum IAiE PAN, Ośrodek Badań nad Kulturą Późnego Antyku i Wczesnego Średniowiecza we Wrocławiu (maszynopis).

Krąpiec M. 2001b. Badania dendrochronologiczne prób drewna pozyskanych podczas prac archeologicznych związanych z budową autostrady A-4 ze stanowiska Milejowice 19 (ob. 914). Kraków: Archiwum IAiE PAN, Ośrodek Badań nad Kulturą Późnego Antyku i Wczesnego Średniowiecza we Wrocławiu (maszynopis).

Krąpiec M. 2003. Analiza dendrochronologiczna prób drewna pozyskanych podczas prac archeologicznych związanych z budową autostrady A-4 ze stanowiska Milejowice 19 (studnia ob. 965). Kraków: Archiwum IAiE PAN, Ośrodek Badań nad Kulturą Późnego Antyku i Wczesnego Średniowiecza we Wrocławiu (maszynopis).

Kufel-Diakowska B. 2019. Raport z analizy traseologicznej przedmiotów kamiennych ze stanowiska Milejowice 19, pow. wrocławski. Wrocław: Archiwum IAiE PAN, Ośrodek Badań nad Kulturą Późnego Antyku i Wczesnego Średniowiecza we Wrocławiu (maszynopis).

Lock G. (2001). Theorising the Practice or Practicing the Theory: Archaeology and GIS. Archaeologia Polona, 39, 153-164.

Maetzke G. (1986). Źródła archeologiczne jako odwzorowanie procesu społeczno-kulturowego. In: W. Hensel. G. Donato, S. Tabaczyński (eds), Teoria i praktyka badań archeologicznych, t. I, Przesłanki metodologiczne (246-302). Wrocław-Warszawa-Kraków-GdańskŁódź: Ossolineum.

Marciniak A., Tabaczyński S. (2017). Geneza i rozwój nierówności społecznych w paradygmatach badawczych 
archeologii. Zarys problematyki. Przeglad Archeologiczny, 65, 45-52.

Markiewicz M. (2019). Visual presentation of settlement complexes from the early Iron Age from Milejowice, site 19, and selected problems of 3D modelling in archaeology. Przegląd Archeologiczny, 67, 101-118.

Medyńska-Gulij B. (2011). Kartografia i geowizualizacja. Warszawa: Wydawnictwo Naukowe PWN.

Pazdur A. 2001. Sprawozdanie nr 11/2011 z wykonania oznaczeń metodą C-14 w Laboratorium C-14 Instytutu Fizyki Politechniki Śląskiej w Gliwicach. Gliwice: Archiwum IAiE PAN, Ośrodek Badań nad Kulturą Późnego Antyku i Wczesnego Średniowiecza we Wrocławiu (maszynopis).

Przybyła M.S., Blajer W. (2008). Struktury osadnicze $w$ epoce brąu $i$ wczesnej epoce żelaza na obszarze podkarpackiej wysoczyzny lessowej między Wisłokiem a Sanem. Kraków: Wydawnictwo Uniwersytetu Jagiellońskiego.

Rączkowski W. (2012). Metody w archeologii. In: S. Tabaczyński, A. Marciniak, D. Cyngot, A. Zalewska (eds), Przeszłość społeczna. Próba konceptualizacji (367408). Poznań: Wydawnictwo Poznańskie.

Rieckhoff S., Biel J. (2001). Die Kelten in Deutschland. Stuttgart: Konrad Theiss.

Sadowski K., Włodarski W. 2004. Analiza geomorfologiczna stanowiska archeologicznego Milejowice 19. Poznań: Archiwum IAiE PAN, Ośrodek Badań nad Kulturą Późnego Antyku i Wczesnego Średniowiecza we Wrocławiu (maszynopis).

Schlette F. (1984). Die Kunst der Hallstattzeit. Leipzig: E.A. Seemann Verlag.

Skowron J. (2007). Die Wiederspiegelung der gesellschaftlichen Struktur auf Grund von Raumplanung des Siedlungskomplexes der Przeworsk Kultur in Rawa
Mazowiecka (Mittelpolen) - eine einfache Siedlung und eine Hofsiedlung. Sprawozdania Archeologiczne, 39, 9-40.

Tabaczyński S., Zalewska A. (2012). Ku istotnościowej koncepcji źródła archeologicznego. Uwagi na temat aktualnej kondycji myśli teoretycznej w badaniu przeszłości społecznej. Wprowadzenie. In: S. Tabaczyński, A. Marciniak, D. Cyngot, A. Zalewska (eds), Przeszłość społeczna. Próba konceptualizacji (17-28). Poznań: Wydawnictwo Poznańskie.

Tajer A. (2016). Sídliště z doby halštatské z Podhoří u Lipníku nad Bečvou, okr. Přerov. Praehistorica, 33, 380404.

Trebsche P. (2010). Architektursoziologie und Prähistorische Archäologie: Methodische Überlegungen und Aussagepotenzial. In: P. Trebsche, N. Müller-Scheeßel, S. Reinholdt (eds), Der gebaute Raum. Bausteine einer Architektursoziologie vormoderner Gesellschaften (143-170). Münster, New York, München, Berlin: Waxmann.

Urbański J. (1997). Zrozumieć GIS. Analiza informacji przestrzennej. Warszawa: Wydawnictwo Naukowe PWN.

Urbański J. (2008). GIS w badaniach przyrodniczych. Gdańsk: Wydawnictwo Uniwersytetu Gdańskiego.

Vokolek V., Sedláček R. (2010). The Hallstatt Age "Herrensitz" and Patterns of Urban Settlement in Opatovice nad Labem (Pardubice District, Eastern Bohemia). In: B. Gediga, W. Piotrowski (eds), Rola głównych centrów kulturowych $w$ ksztaltowaniu oblicza kulturowego Europy Środkowej we wczesnych okresach epoki żelaza (265-282). Biskupin-Wrocław: Muzeum Archeologiczne w Biskupinie, Polska Akademia Nauk - Oddział we Wrocławiu, IAiE PAN. 
Author's addresses:

Mgr Aneta Buchner

Ośrodek Badań nad Kulturą

Późnego Antyku i Wczesnego Średniowiecza

Instytut Archeologii i Etnologii PAN

ul. Więzienna 6

50-118 Wrocław

e-mail: aneta.buchner@gmail.com

(iD https://orcid.org/0000-0002-0920-7548

Prof. UAM dr hab. Ewa Bugaj

Wydział Archeologii

Uniwersytet im. Adama Mickiewicza

ul. Uniwersytetu Poznańskiego 7

61-614 Poznań

e-mail: ebugaj@amu.edu.pl

(iD https://orcid.org/0000-0001-8245-8063 


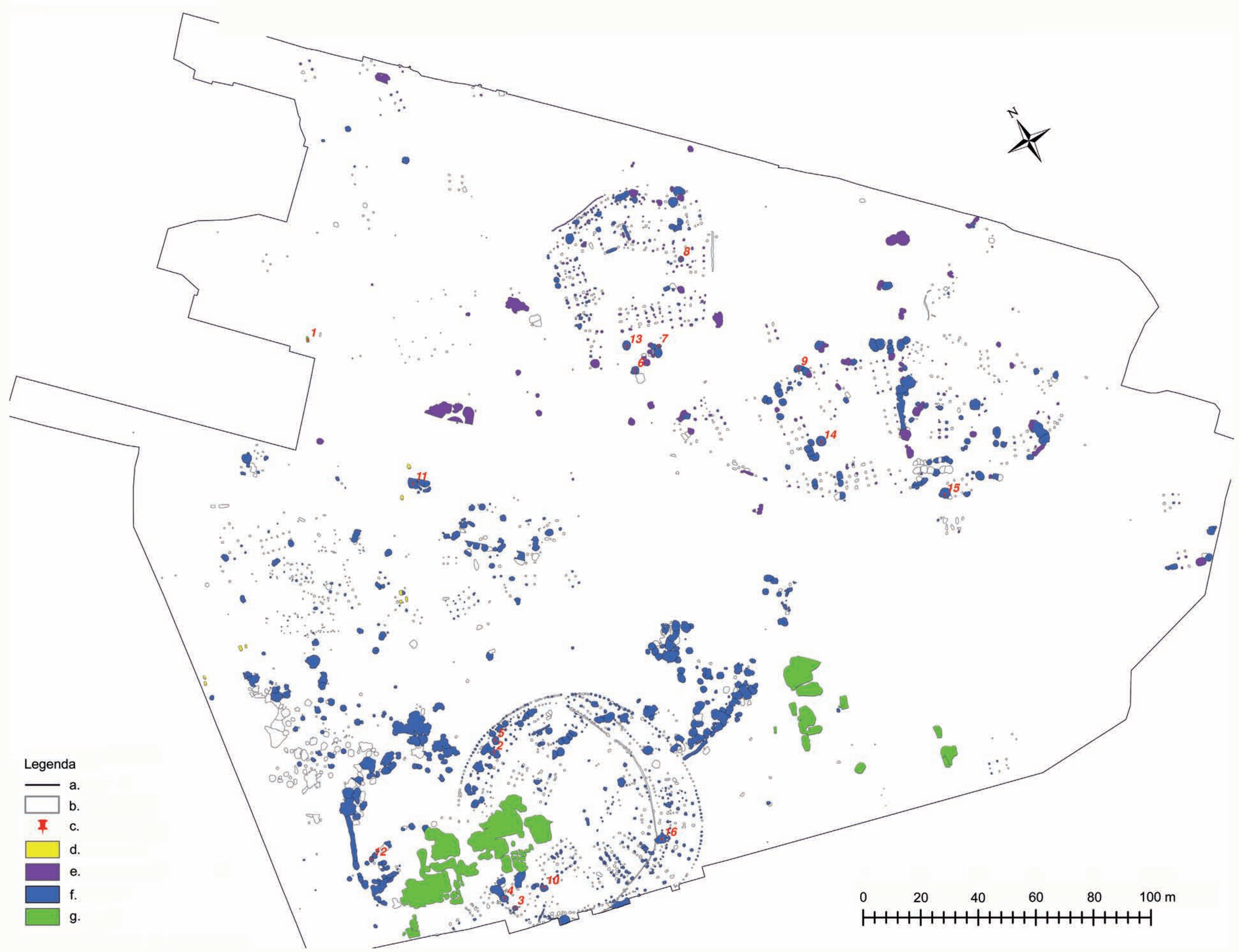




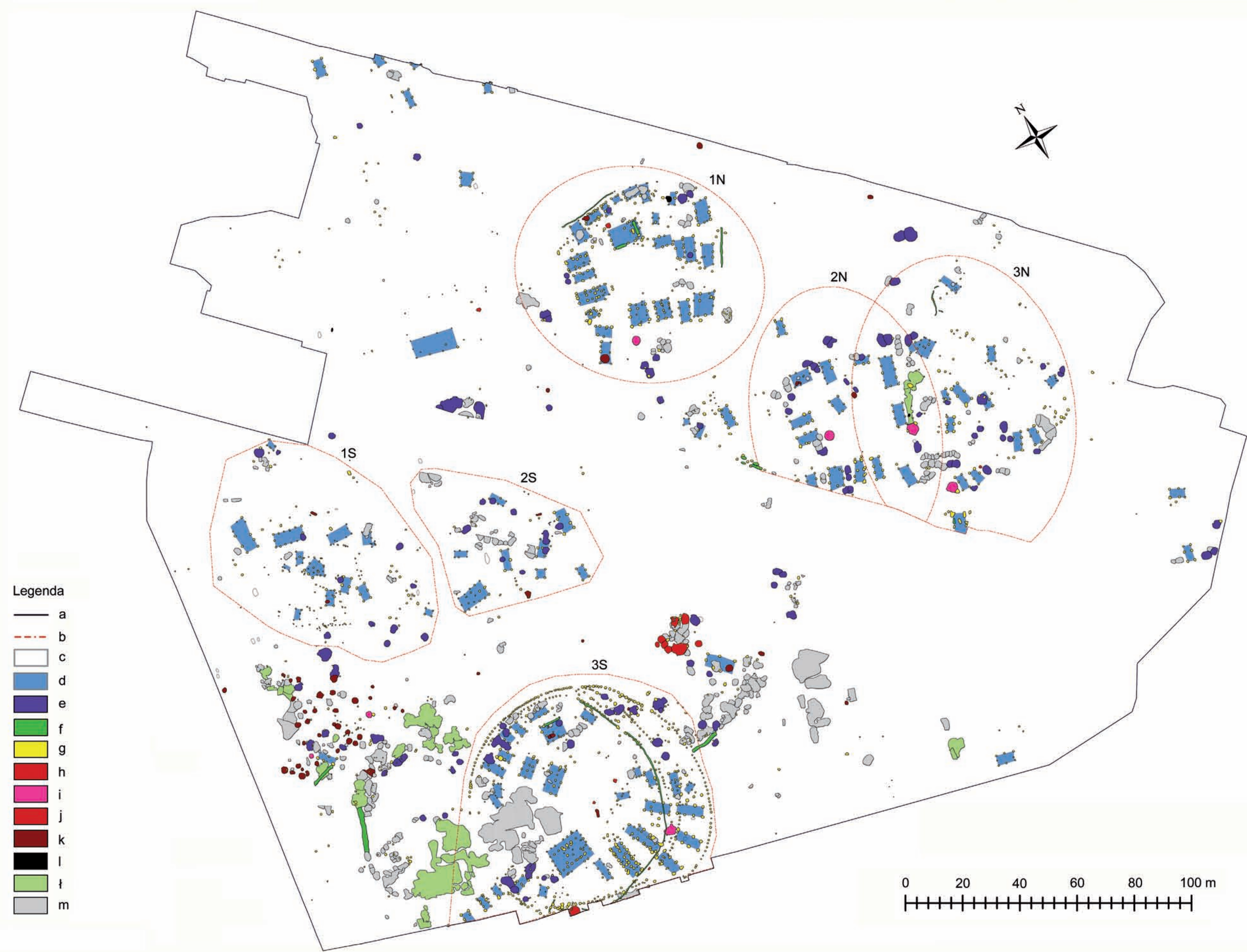

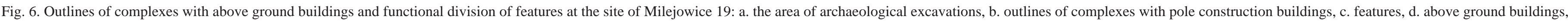
e. dug-out huts, f. fencing elements, g. post holes, h. votive pits, i. wells, j. bronze-working workshop, k. storage pits, l. hearths, ł. resource pits, m. undefined pits (by A. Buchner) 


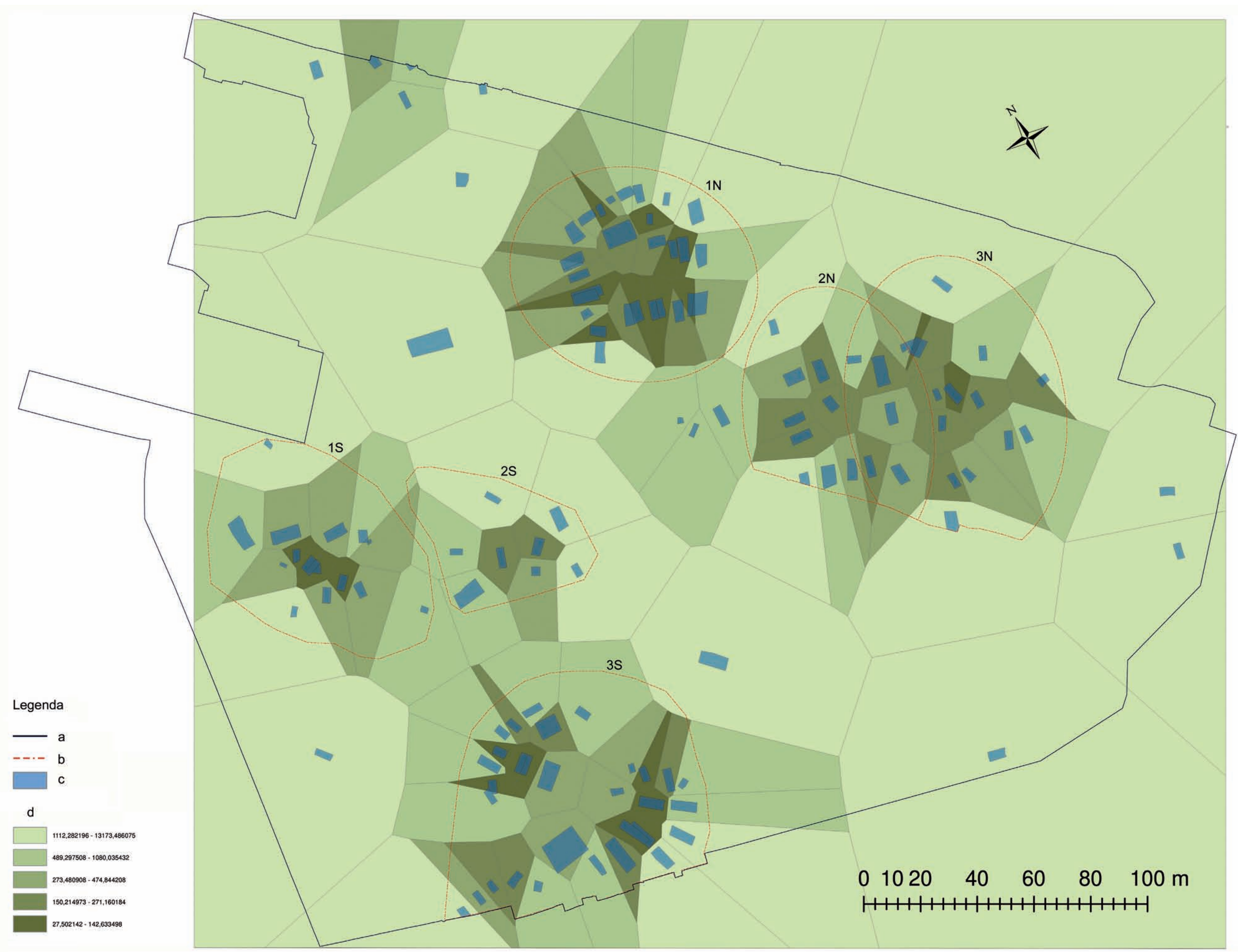

Fig. 7. Analysis of spatial division at the site of Milejowice 19 carried out with the use of Thiessen polygons, basing on the feature class "above ground buildings": a. area of archaeological excavations, b. outlines of complexes with pole construction buildings, c above ground buildings, d. net of Thiessen polygons - classification of the surface of polygons using quantile estimation in $\mathrm{m}^{2}$ (by A. Buchner) 


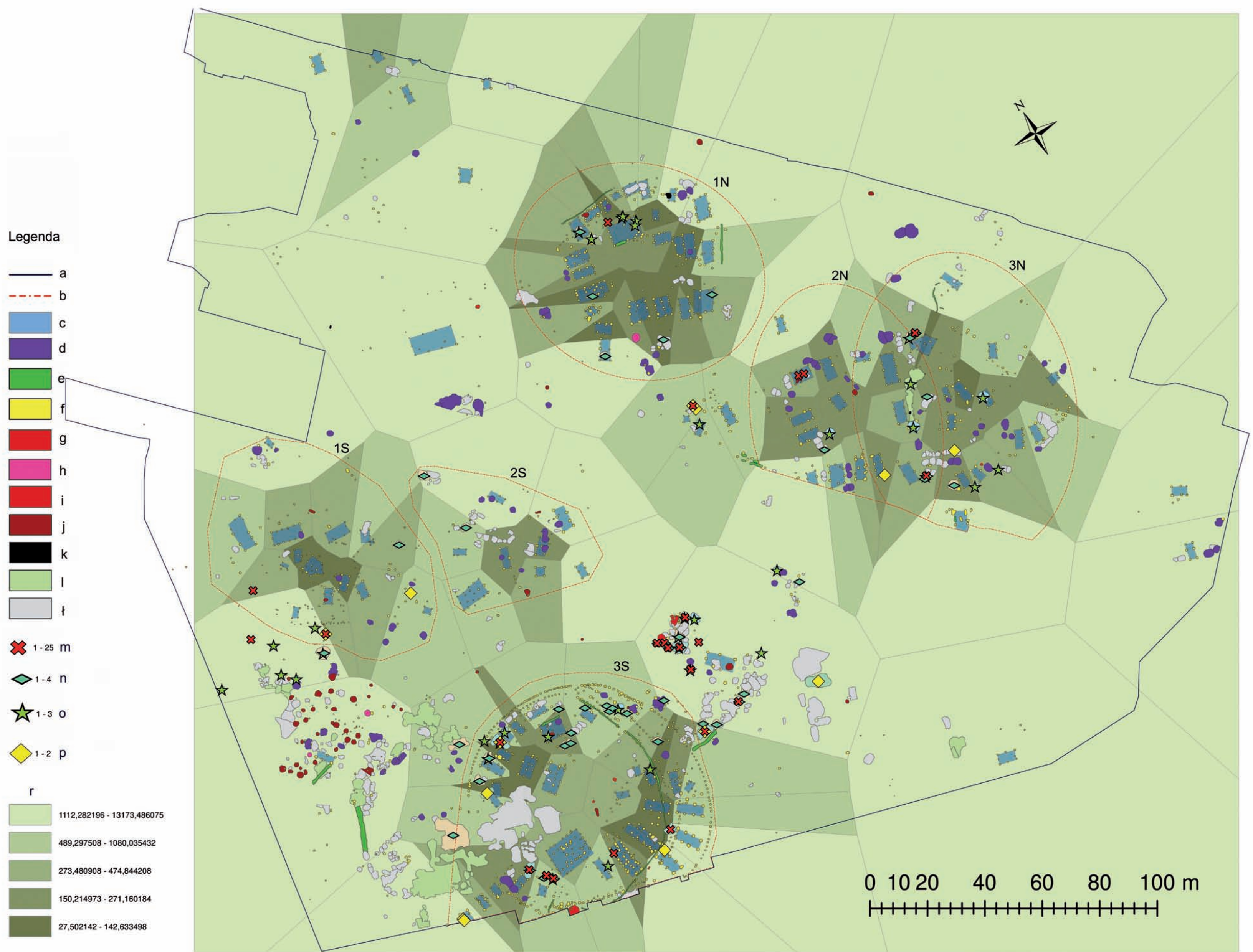

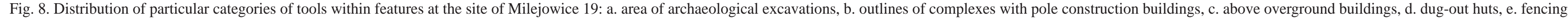
elements, f. post holes, g. votive pits, h. wells, i. bronze-working workshop, j. storage pits, k. hearths, l. resource pits, ł. undefined pits, m. bronze items, n. bone tools, o. stone tools, p. weaving tools, r. net of Thiessen polygons (by A. Buchner) 


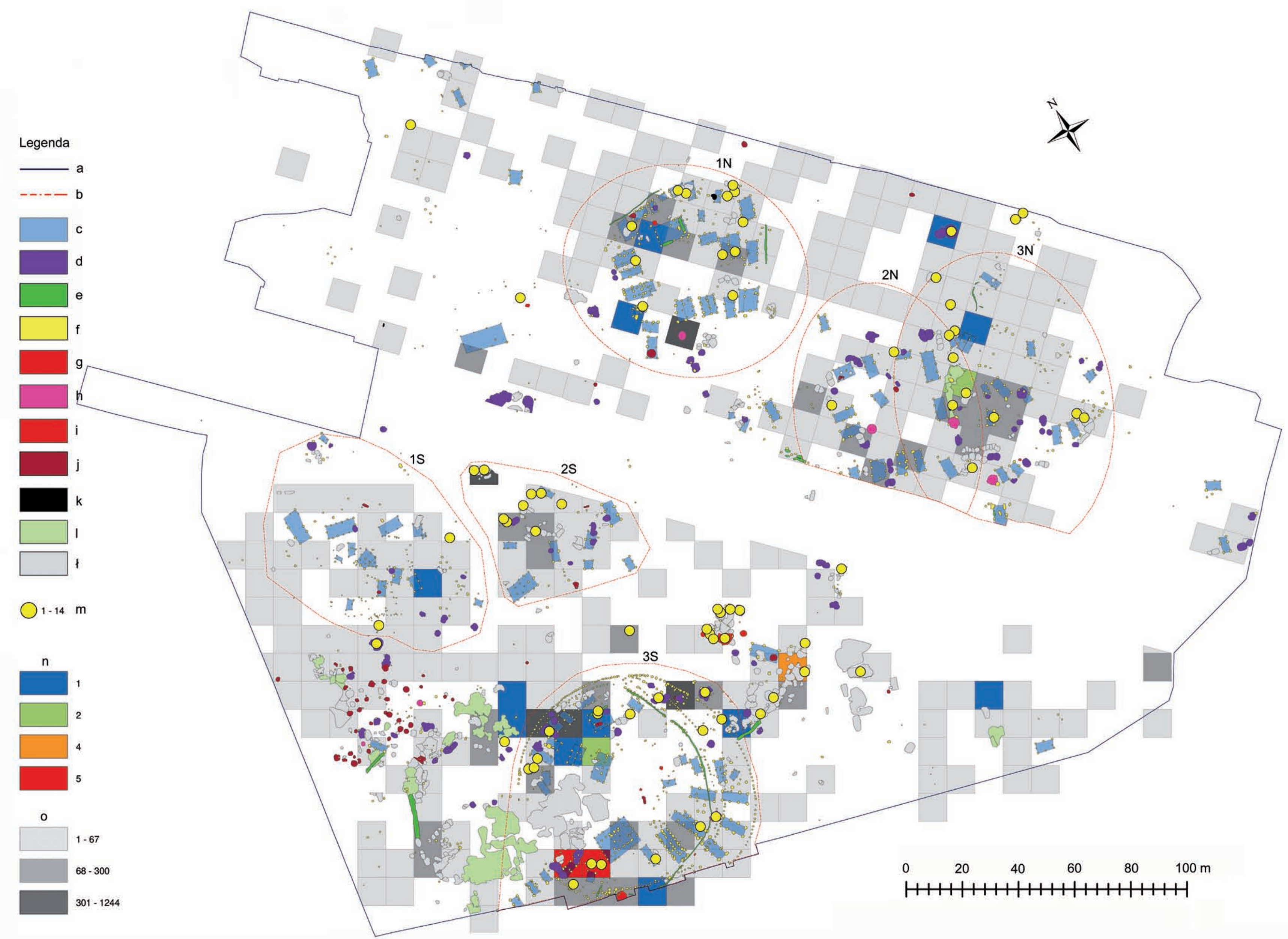

Fig. 10. Distribution of painted ceramics in the features and cultural layer at the site of Milejowice 19: a. area of archaeological excavations, b. outlines of complexes with pole construction buildings, c. above ground buildings, d. dug-out huts, e. fencing elements, f. post holes, g. votive pits, h. wells, i. bronze-working workshop, j. storage pits, k. hearths, l. resource pits, $\begin{aligned} & \text {. undefined pits, m. number of painted pottery fragments in features, } \\ & \text { n. number of painted pottery fragments in the cultural layer, o. number of pottery fragments in the cultural layer (by A. Buchner) }\end{aligned}$ 


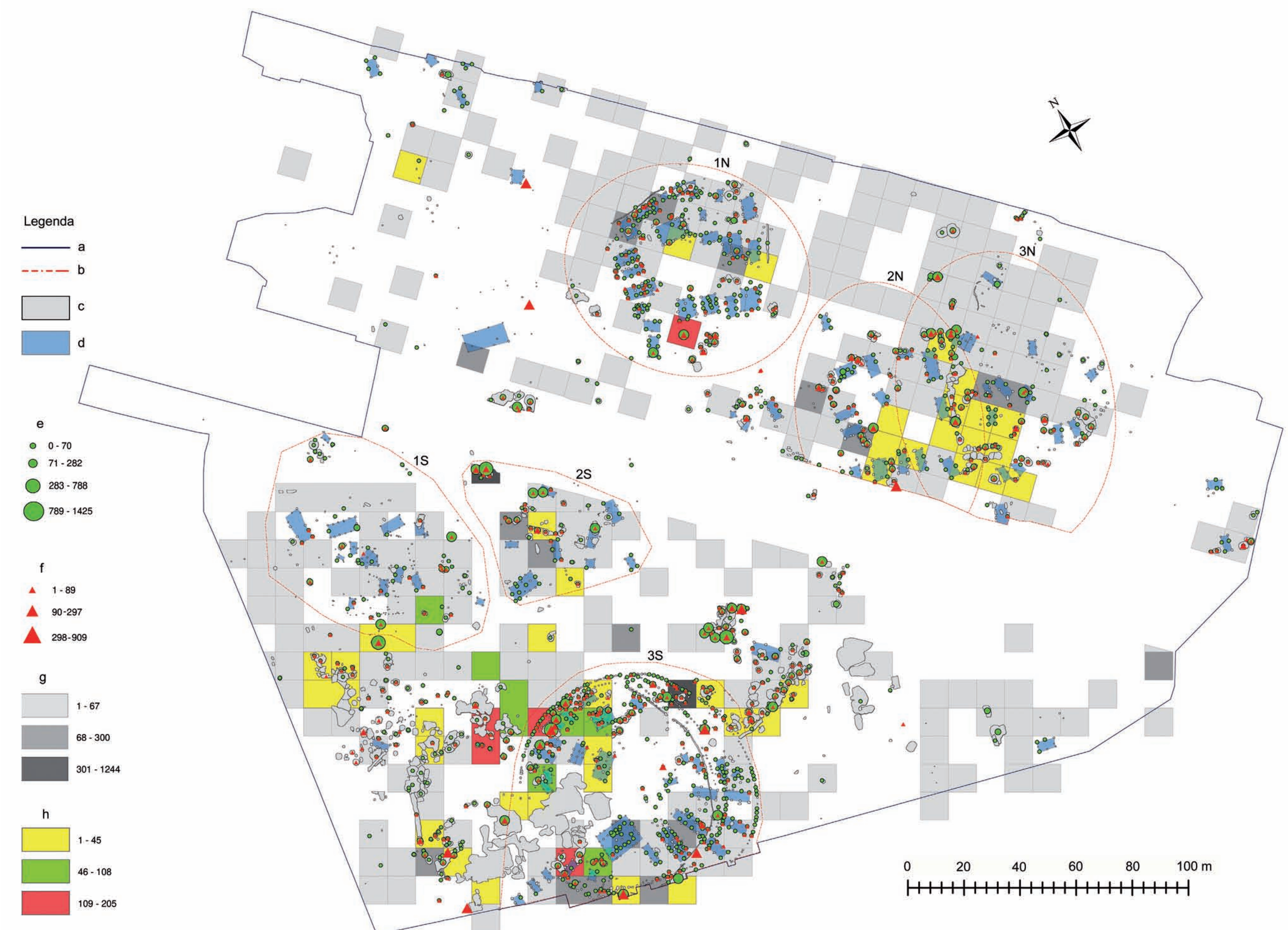

Fig. 12. Distribution of mass material in the features and cultural layer at the site of Milejowice 19: a. area of archaeological excavations, b. outlines of complexes with pole construction buildings, c. features, d. above ground buildings, e. number of pottery fragments in features, f. number of bone fragments in features, g. number of pottery fragments in the cultural layer, h. number of bone fragments in the cultural layer (by A. Buchner) 